\title{
DEEP-WATER INCISED VALLEY DEPOSITS AT THE EDIACARAN-CAMBRIAN BOUNDARY IN SOUTHERN NAMIBIA CONTAIN ABUNDANT TREPTICHNUS PEDUM
}

\author{
JONATHAN P. WILSON, ${ }^{1 *}$ JOHN P. GROTZINGER, ${ }^{1}$ WOODWARD W. FISCHER,${ }^{1}$ KEVIN P. HAND,${ }^{2}$ SÖREN JENSEN, ${ }^{3}$ \\ ANDREW H. KNOLL, ${ }^{4}$ JOHN ABELSON,${ }^{5}$ JOANNAH M. METZ, ${ }^{1}$ NICOLA MCLOUGHLIN, ${ }^{6}$ PHOEBE A. COHEN, ${ }^{7}$ and \\ MICHAEL M. TICE 8 \\ ${ }^{1}$ Division of Geological and Planetary Sciences, California Institute of Technology, Pasadena, California 91125, USA, jpwilson@caltech.edu, grotz@gps.caltech.edu, \\ wfischer@caltech.edu, joannah@its.caltech.edu; ${ }^{2}$ Jet Propulsion Laboratory, California Institute of Technology, Pasadena, California 91109, USA, \\ Kevin.P.Hand@jpl.nasa.gov; ${ }^{3}$ Área de Paleontologia, Universidad de Extremadura, Badajoz, Spain, soren@unex.es; ${ }^{4}$ Department of Organismic and Evolutionary \\ Biology, Harvard University, Cambridge, Massachusetts 02138, USA, aknoll@oeb.harvard.edu; ${ }^{5}$ Department of Biology, California Institute of Technology, and The \\ Agouron Institute, Pasadena, California 91125, USA, jabelson@biochem.ucsf.edu; ${ }^{6}$ Department of Earth Science and Center for Geobiology, University of Bergen, \\ Norway, Nicola.Mcloughlin@geo.uib.no; ${ }^{7}$ Department of Earth, Atmospheric, and Planetary Sciences, Massachusetts Institute of Technology, Cambridge, \\ Massachusetts 02139, USA, pcohen@mit.edu; ${ }^{8}$ Department of Geology and Geophysics, Texas A\&M, College Station, Texas 77843, USA, tice@geo.tamu.edu
}

\begin{abstract}
Valley-filling deposits of the Nama Group, southern Namibia, record two episodes of erosional downcutting and backfill, developed close together in time near the Ediacaran-Cambrian boundary. Geochronological constraints indicate that the older valley fill began $539.4 \pm 1$ Ma or later; the younger of these deposits contains unusually well-preserved populations of the basal Cambrian trace fossil Treptichnus pedum. Facies analysis shows that $T$. pedum is closely linked to a nearshore sandstone deposit, indicating a close environmental or taphonomic connection to very shallow, mud-draped sandy seafloor swept by tidal currents. Facies restriction may limit the biostratigraphic potential of $T$. pedum in Namibia and elsewhere, but it also illuminates functional and ecological interpretation. The $T$. pedum tracemaker was a motile bilaterian animal that lived below the sediment-water interface-propelling itself forward in upward-curving projections that breached the sediment surface. The $T$. pedum animal, therefore, lived infaunally, perhaps to avoid predation, surfacing regularly to feed and take in oxygen. Alternatively, the $T$. pedum animal may have been a deposit feeder that surfaced largely for purposes of gas exchange, an interpretation that has some support in the observed association of $T$. pedum with mud drapes. Treptichnus pedum provides our oldest record of animals that combined anatomical and behavioral complexity. Insights from comparative biology suggest that basal Cambrian T. pedum animals already possessed the anatomical, neurological, and genetic complexity needed to enable the body plan and behavioral diversification recorded by younger Cambrian fossils.
\end{abstract}

\section{INTRODUCTION}

The trace fossil Treptichnus pedum is widely recognized for its role in marking the beginning of the Cambrian period in stratigraphic successions throughout the world. In the global stratotype section in Newfoundland, the initial boundary of the Cambrian Period is defined by a point placed with specific reference to the first appearance of $T$. pedum (Narbonne et al., 1987; Brasier et al., 1994), a point also marked by a distinct change in lithology (Myrow and Hiscott, 1991, 1993; Myrow, 1992). The degree to which the first stratigraphic occurrence of T. pedum reflects its first evolutionary appearance - and, therefore, the degree to which global first appearances of $T$. pedum can be correlated to the boundary stratotype - depends on both its environmental distribution and facies development within basins (e.g., Gehling et al., 2001). To date, sedimentological insights into the environmental

* Corresponding author; present address: Department of Biology, Haverford College, Haverford, Pennsylvania 19041, USA.

Published Online: April 2012

Copyright ${ }^{\complement}$ 2012, SEPM (Society for Sedimentary Geology) distribution of $T$. pedum remain limited, sustaining a level of uncertainty regarding the biostratigraphic resolution of regional first appearances. At the same time, greater understanding of the facies distribution of $T$. pedum can aid in the biological interpretation of this key record of early animal diversification.

Ediacaran-Cambrian sections in Namibia have become a focus for studies of biological and environmental evolution because of the rare colocation of ash beds suitable for radiometric dating, several hundred meters of intercalated carbonates for stable isotope chemostratigraphy, abundant body fossils of canonical Ediacaran and coeval calcified fossils, and some of the earliest trace fossils that record motile feeding (Grotzinger et al., 1995a). The Ediacaran-Cambrian Boundary (ECB) itself occurs within a large erosional unconformity (Grotzinger et al., 1995a), and the precise stratigraphic relationships among the earliest trace fossils, carbon isotopic excursions, and geochronologic tie points near the boundary remain unclear (Grotzinger and Miller, 2008). Investigations across the southern portion of Namibia have pointed to a number of locations where incised valleys may be found (e.g., Germs, 1983; Saylor and Grotzinger, 1996), and the current consensus view regarding the stratigraphic position of the ECB in Namibia is to regard the base of the incised valleys as marking the boundary, with valley fill deposits representing younger strata (Germs, 1983; Gresse and Germs, 1993; Grotzinger et al., 1995a; Saylor et al., 1995; Saylor and Grotzinger, 1996; Grotzinger and Miller, 2008; Blanco et al., 2011); this perspective, however, is not universal (Geyer, 2005). This study investigates a series of exposures of the incised valleys on Sonntagsbrunn Farm 105, approximately $100 \mathrm{~km}$ southwest of Keetmanshoop, Namibia (Fig. 1).

Three-dimensional exposures of incised valleys at Sonntagsbrunn Farm 105 reveal detailed paleoenvironmental relationships for the trace fossils that define the Ediacaran-Cambrian boundary in the Newfoundland stratotype section. In Namibia, valley-filling siliciclastic sediments display a range of facies, some of which, but not all, contain spectacular occurrences of $T$. pedum. These rocks lack the penetrative strain and metamorphic overprints that affect the Global Boundary Stratotype Section and Point (GSSP) section in Newfoundland. Investigating the differential occurrence of $T$. pedum traces in these facies, thus, can provide useful insight into the taphonomy of the traces, the environmental ecology of the tracemaker, and the challenges associated with using this trace fossil as a robust marker of the ECB from region to region (Strauss et al., 1992).

\section{GEOLOGIC SETTING}

The Nama Group in southern Namibia is a 3000-meter-thick succession of mixed shallow-marine and fluvial, siliciclastic and 


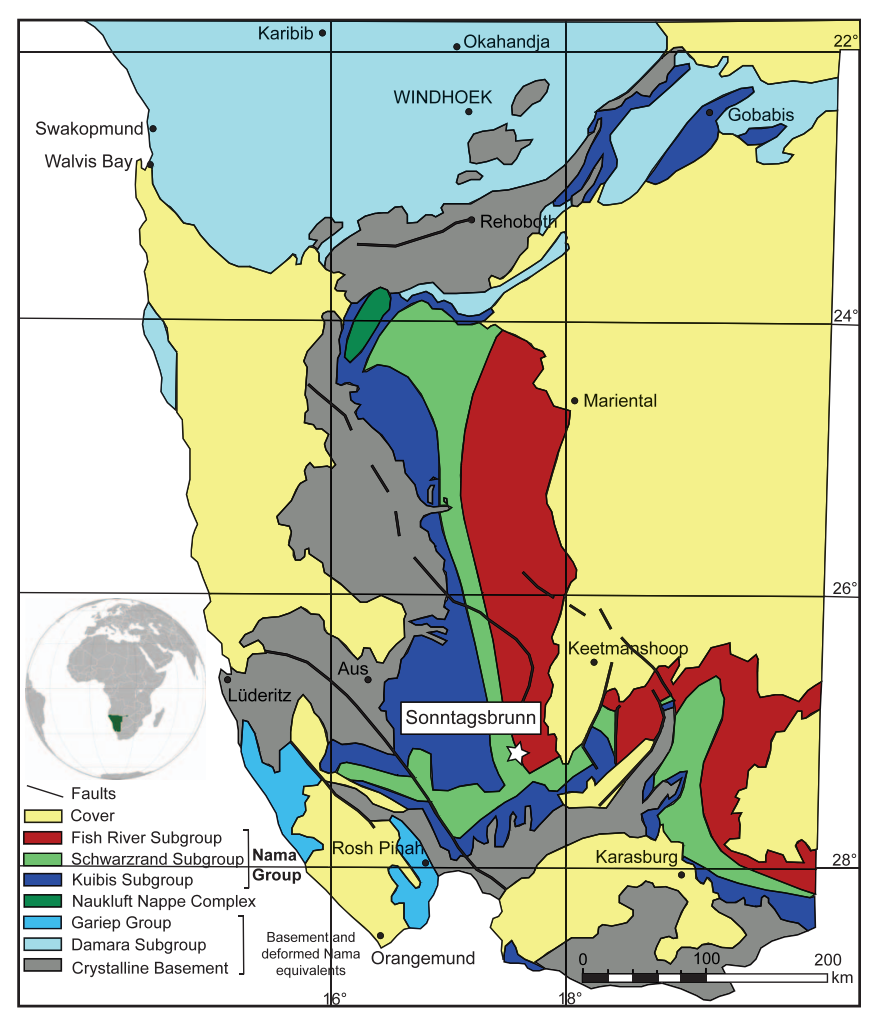

FIGURE 1-Geologic map of Namibia with the study area, Sonntagsbrunn Farm 105, marked.

carbonate rocks exposed across much of the southern portion of the country. This succession postdates the Marinoan glaciation and, possibly, the first appearance of Cloudina; the upper part contains the $\mathrm{ECB}$, and thus records an interval of time from approximately $550 \mathrm{Ma}$ to $535 \mathrm{Ma}$ (Grotzinger and Miller, 2008). The Nama Group is divided into three units, from bottom to top: the Kuibis, Schwarzrand, and Fish River subgroups (Fig. 1). In total, the Nama Group covers over $40,000 \mathrm{~km}^{2}$; approximately one-third of this area is represented by the middle portion of this stratigraphic package - the Ediacaran-age Schwarzrand Subgroup.

The Schwarzrand Subgroup was deposited in a foreland basin in response to crustal loading from thrust sheets as subduction occurred along the Gariep Belt ( $\sim 100 \mathrm{~km}$ west-southwest of the field site) and farther north along the Damara Belt, south of Windhoek (Germs, 1983; Gresse and Germs, 1993; Saylor, 2003); a well-developed thrust belt occurs along the western limit of Nama Group exposures (Saylor and Grotzinger, 1996).

The Schwarzrand Subgroup consists of mixed siliciclastics and carbonates, with fine-grained siliciclastics predominating near the base of the unit. Previous work has documented the sequence stratigraphy, carbonate sedimentology, and geomorphic evolution of carbonate ramps and siliciclastic-dominated packages within the subgroup (Germs, 1983; Saylor et al., 1995; Saylor and Grotzinger, 1996; Saylor, 2003; DiBenedetto and Grotzinger, 2005; Grotzinger and Miller, 2006). Carbonate lithologies are best developed on the western margin of the basin, in the depocenter where siliciclastic input was insufficient to fill the accommodation.

The Schwarzrand Subgroup has been divided into three formations, from bottom to top: the Nudaus, Urusis, and Nomtsas formations. The Nudaus Formation contains two sequences of shale and sandstone, with rare occurrences of enigmatic carbonaceous tubes (Cohen et al., 2009) and the Ediacaran body fossils Pteridinium and Rangea (Grotzinger et al., 1995a; Narbonne et al., 1997). The overlying Urusis Formation contains two carbonate platform sequences (Huns and
Spitskopf members) underlain by shelf sandstone and shale units (Nasep and Feldschuhhorn members, respectively). Urusis Formation fossils include abundant populations of the probable alga Vendotaenia (Cohen et al., 2009), calcified metazoans associated with microbial reefs (Grotzinger et al., 1995b), Ediacaran body fossils (Narbonne et al., 1997), and rare animal traces (Jensen and Runnegar, 2005). Incised valley deposits cut into the top of the Urusis Formation and are filled in by shales, siltstones, and sandstones of the Nomtsas Formation (Germs, 1983). The Urusis-Nomtsas formation boundary contains incised valleys and multiple ash beds across the southern part of Namibia (Saylor et al., 1995). Sequential ash beds dated at $545.1 \pm 1$, $543.3 \pm 1$, and $539.4 \pm 1 \mathrm{Ma}$ by U-Pb systematics on volcanic zircons (Grotzinger et al., 1995b) are distributed throughout the Schwarzrand Subgroup and yield superior age control, compared with contemporaneous localities in Avalonia.

At Sonntagsbrunn Farm 105 (27 $7^{\circ} 5^{\prime} 56^{\prime \prime}$ S, $\left.17^{\circ} 37^{\prime} 43^{\prime \prime} \mathrm{E}\right)$, the Nomtsas Formation incises into the upper two members of the underlying Urusis Formation, forming two discrete incised valleys (Fig. 2). These are exposed in cross section in the walls of the present-day canyon, carved by a tributary of the Fish River. Valley fill units are superimposed on one another, and can be traced for hundreds of meters in plan view; incised valley widths appear to be on the order of $200 \mathrm{~m}$ (Fig. 3). The first valley fill sequence (termed VF1) achieves greater maximum width than the second, and consists of nonfossiliferous, deep-water laminated mudstones (Figs. 4, 6). The second valley fill sequence (termed VF2; Figs. 3, 5, 6) contains a wide variety of sedimentary structures indicating unidirectional currents, along with abundant trace fossils assignable to Treptichnus pedum (Figs. 10-15).

We measured several sections on Sonntagsbrunn Farm 105 that include VF1 and VF2, with particular focus on identifying $T$. pedumbearing facies. Several sites with VF2 deposits contained abundant traces, and two in particular (Visionarium $\left[27^{\circ} 16^{\prime} 16.89^{\prime \prime} \mathrm{S}, 17^{\circ} 38^{\prime} 18.82^{\prime \prime} \mathrm{E}\right]$ and section 4 [ $\left.27^{\circ} 16^{\prime} 23.02^{\prime \prime} \mathrm{S}, 17^{\circ} 38^{\prime} 17.76^{\prime \prime} \mathrm{E}\right]$; see Supplementary Data ${ }^{1}$ for Google Maps images) were the source for most of the observations reported here. Trace fossils occur on both sides of the canyon, spread over approximately $1.5 \mathrm{~km}^{2}$ in map view. We photographed $T$. pedum traces in cross section and plan view using a Canon digital SLR camera. Image analysis was performed using the open-source software package ImageJ, currently maintained by the National Institutes of Health (available from: http://rsbweb.nih.gov/ij).

\section{RESULTS STRATIGRAPHY AND SEDIMENTOLOGY}

Within the study area on Sonntagsbrunn 105, measured sections (Figs. 7-8) span the middle and upper portions of the Schwarzrand Subgroup and the overlying Nomtsas Formation (Fig. 7). Images of these lithologies and sedimentary structures may be found in Figure 18.

\section{Urusis Formation: Feldschuhhorn Member}

The Feldschuhhorn Member (sections 1 and 8; Figs, 3, 4, 6) is composed of green-gray fissile shales with iron staining. These can be distinguished from shales within the Nomtsas Formation by their variability in color (Feldschuhhorn shales weather from gray to buff) and the occurrence of tubular microfossils, described by Cohen et al. (2009). Shales are composed of finely laminated mudstones, with streaky siltstone intercalations. The shales contain rare intercalated thin sandstone beds that occasionally contain low-angle cross-bedding and calcareous, concretionary cements. Massive sandstone beds are also intercalated within the shales, and range in thickness up to $10 \mathrm{~cm}$. Associated tubular fossils are 1-2 mm wide, curving, flattened

\footnotetext{
${ }^{1}$ palaios.ku.edu
} 

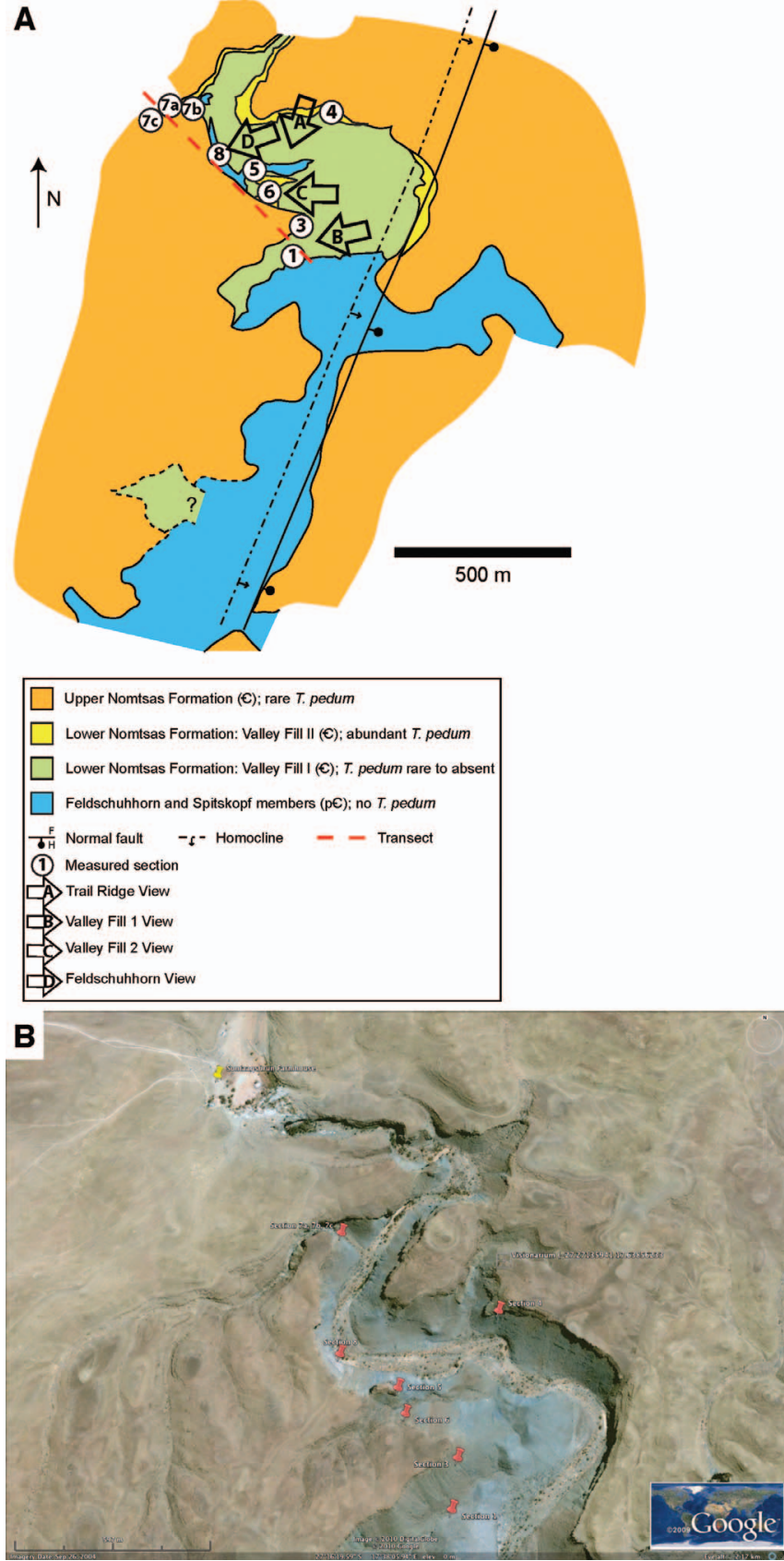

FIGURE 2-A) Local map of study area, showing location of measured sections and viewing directions of annotated photomontages (arrows). Dashed line indicates line of transect (Figs. 4 and 20). B) Google Earth image of study area, showing location of local landmarks (roads and Sonntagsbrunn farm), measured sections and locality of extraordinarily abundant Treptichnus pedum traces (Visionarium). Numbers are latitude and longitude.

compressions that are pyritic in fresh exposure and rusty red on weathered surfaces (Cohen et al., 2009).

The Feldschuhhorn shales are interpreted to have formed near or below storm wave base, based on the absence of fair-weather waveinduced structures, and only the rare appearance of low-angle lamination that probably represents small-scale hummocky crossstratification. Interbedded, massive sandstone beds may represent deposition from hyperpycnal flows (Lamb et al., 2008). Working on Swartkloofberg 95, approximately $110 \mathrm{~km}$ to the west of the study area, Saylor (2003) described this environment as storm-influenced shelf; however, our observations from Sonntagsbrunn 105 suggest that, regionally, much of the deposition occurred largely below storm wave base (SWB) during Feldschuhhorn time.

\section{Urusis Formation: Spitskopf Member}

A limited thickness of the lower Spitskopf Member can be seen in section 8. It consists of shale and siltstone much like those of the Feldschuhhorn Member, but grades upward into black, thin-bedded, lime mudstone interpreted as the base of the upper Spitskopf Member. The lime mudstones occur at the top of section 8 and are visible in outcrop (Fig. 6). Younger Spitskopf strata were removed by erosion prior to the onset of Nomtsas deposition.

Westward, within Swartkloofberg 95, the Spitskopf Member contains much thicker cycles of alternating siliciclastics and stromatolitic carbonate; the lowermost carbonates units are karst-capped and their depositional environment has been interpreted as a high-energy, waveswept shelf (Saylor, 2003). Within the study area, Spitskopf Member thicknesses never exceed $2 \mathrm{~m}$, limiting our ability to correlate precisely with the thicker, western sections.

On Sonntagsbrunn 105 the upper Spitskopf Member is not present as an intact, laterally continuous unit, having been differentially eroded during VF1 and VF2 incision events. In one location (Fig. 3), however, a single large block represents collapse of the upper Spitskopf at the top of the Valley Fill 1 sequence. This block contains carbonate strata over $5 \mathrm{~m}$ thick and, therefore, provides indirect evidence for a once-thicker Spitskopf Member, which was truncated by pre-Nomtsas Formation erosion.

\section{Lower Nomtsas Formation: Valley Fill 1 (VF1)}

The lower part of the Nomtsas Formation (section 3; Figs. 3-5) has previously been recognized to contain an incised valley complex (Germs, 1983; Saylor et al., 1995; Saylor and Grotzinger, 1996; Saylor, 2003; Grotzinger and Miller, 2008). The facies and internal stratigraphy of this incised valley complex have not been described in detail, however. Our observations show that the previous interpretation of a single valley incision event (Saylor, 2003), as observed in a western, downdip location (Swartkloofberg 95), must be modified in our eastern, updip location (Sonntagsbrunn 105) to show two distinct episodes of valley incision, described here as Valley Fill 1 and 2 (VF1 and VF2). Each valley fill sequence delineates a single depositional sequence.

The most abundant facies $(>80 \%)$ in VF1 is composed of finely laminated green to grey shale along with laminated siltstone containing interbedded turbiditic sandstone and occasional carbonate beds. These deposits are observed to onlap pre-incision strata at the margins of the incised valley (Fig. 19). Shales are predominantly drab olive green in color (Fig. 4). Sandstones form thin beds, less than 10-15 cm thick, and are commonly graded and cross-bedded. Evidence of soft-sediment deformation is present within more massive beds. The basal strata of VF1 contain coarse, carbonate-clast conglomerates. Clasts are subangular to subrounded and are derived from black carbonates in the underlying Spitskopf Member. These carbonate conglomerates are lenticular, onlapping the sides of the VF1 basal surface and conforming to its shape, probably due to preferential compaction of the incised valley strata. The upper part of the VF1 infill succession is everywhere truncated by the basal surface of VF2.

The basal VF1 conglomerates are matrix supported and lack any evidence of traction transport or other indicators of fluvial sediment transport. It appears, therefore, that initial valley-fill deposits in the Sonntagsbrunn area were deeper marine in origin, similar to those observed downdip to the west in Swartkloofberg 95 (Saylor and Grotzinger, 1996)

Many incised valleys filled by marine strata show initial deposits indicative of fluvial deposition. In turn, these fluvial deposits point to downcutting and bedrock incision during base-level fall, followed by accumulation of strata during base-level rise (Allen and Posamentier, 


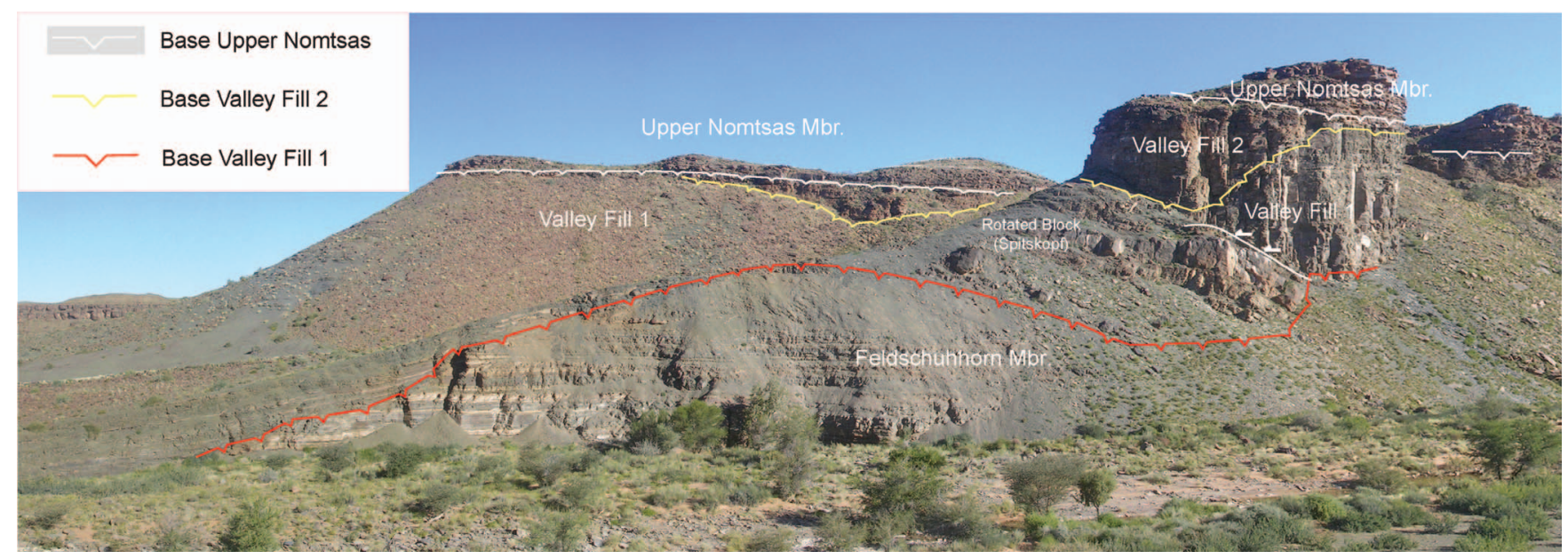

FIGURE 3-Annotated photomosiac of location Trail Ridge, showing incised valley stratigraphy. Valley Fill 1 and Valley Fill 2 cut down to the Feldschuhhorn Member in this location. From the base of the valley to the top of the cliff is approximately $150 \mathrm{~m}$. Stratigraphic thicknesses can be estimated from Figure 7 .

1993). In other cases, however, especially near the shelf break, headward erosion of incised valleys may occur simply by landward propagation of channels formed by mass wasting. In the case of the Nomtsas Formation, it seems the latter scenario may provide the better explanation for the valley incision; valley-filling sediments are all of marine origin, raising the possibility that the incised valleys were not cut by a regional fluvial system. Regional mapping of facies has not revealed evidence for a shelf break (Saylor, 2003), suggesting instead a low-gradient ramp dipping away from Sonntagsbrunn toward western outcrops. The incision mechanism(s) remains ambiguous, but detailed

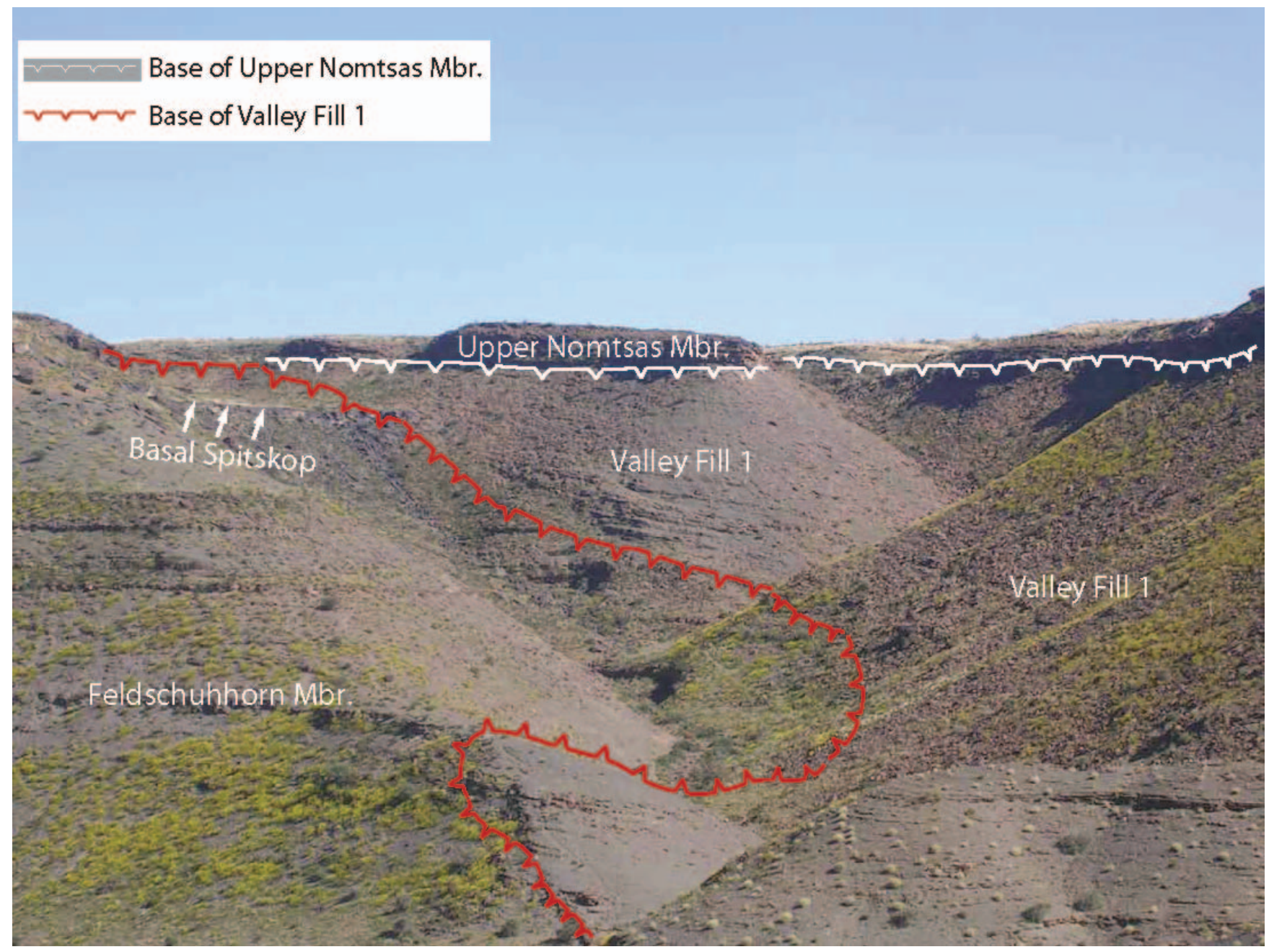

FIGURE 4-Annotated photomosaic of Valley Fill 1, showing relationship between Spitskopf and Feldschuhhorn Members and overlying sheet sandstones of the upper Nomtsas Formation. From the base of the valley to the top of the cliff is approximately $150 \mathrm{~m}$. 


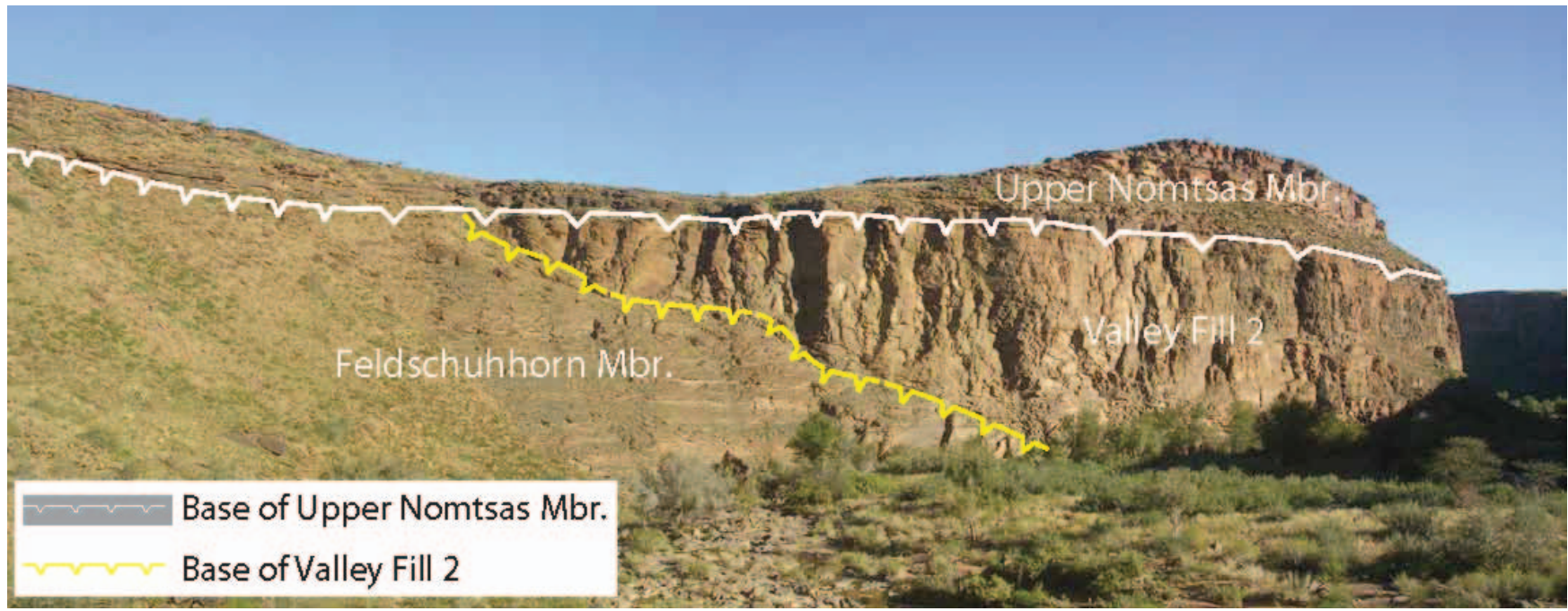

FIGURE 5-Annotated photomosaic of Valley Fill 2 stratigraphy, showing relationship between Feldschuhhorn Member, Valley Fill 2, and Upper Nomtsas Formation. From the base of the valley to the top of the cliff is approximately $150 \mathrm{~m}$.

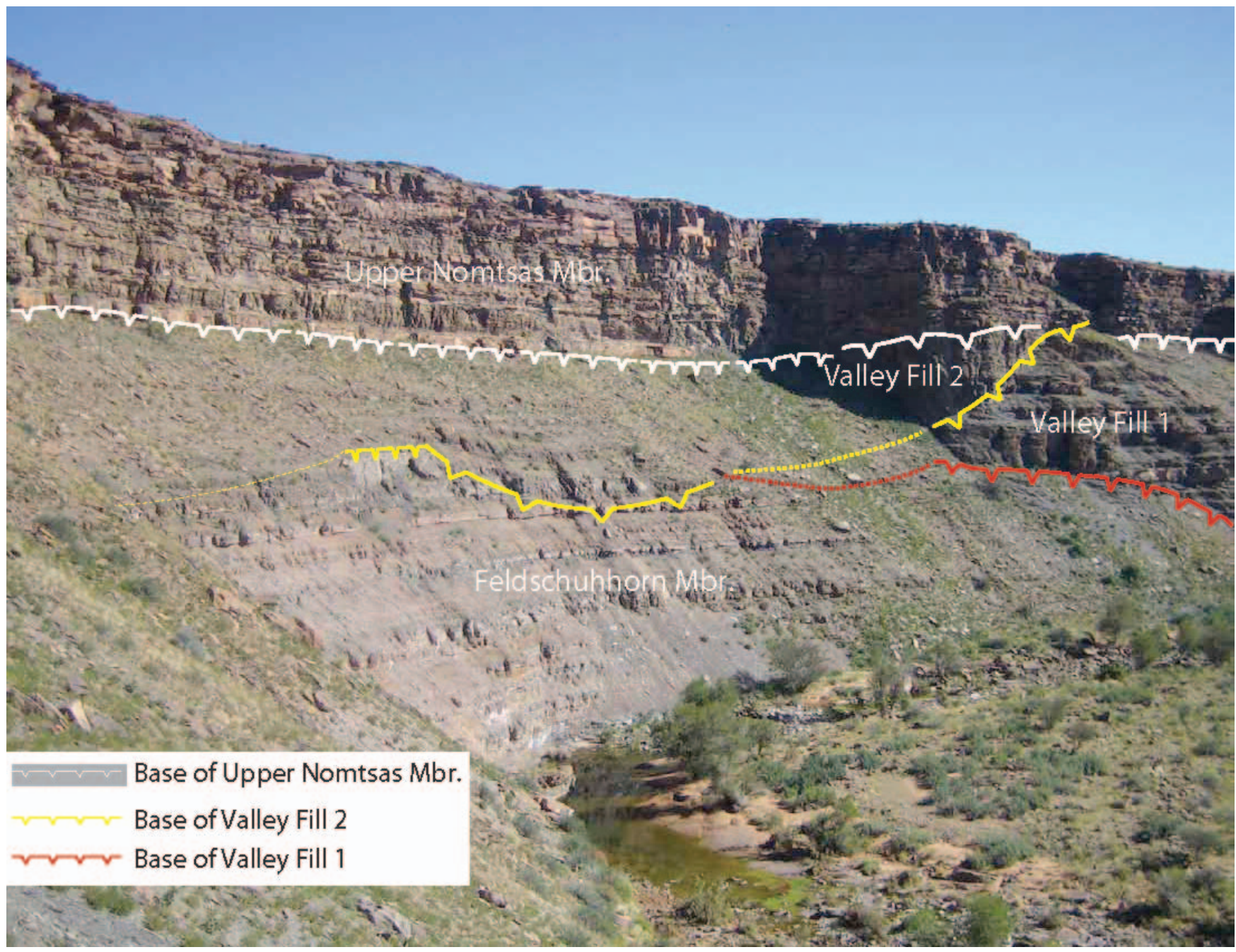

FIGURE 6-Annotated photomosaic of Feldschuhhorn Member, Valley Fill 1, and Valley Fill 2 stratigraphy in relation to the upper Nomtsas Formation. Measured section 8 is through this outcrop of the Feldschuhhorn Member and contains tube-like microfossils (Cohen et al., 2009). Trace of VF1 and VF2 and contact with Feldschuhhorn Member is obscured in center of photo by rubble. From the base of the valley to the top of the cliff is approximately $150 \mathrm{~m}$. 

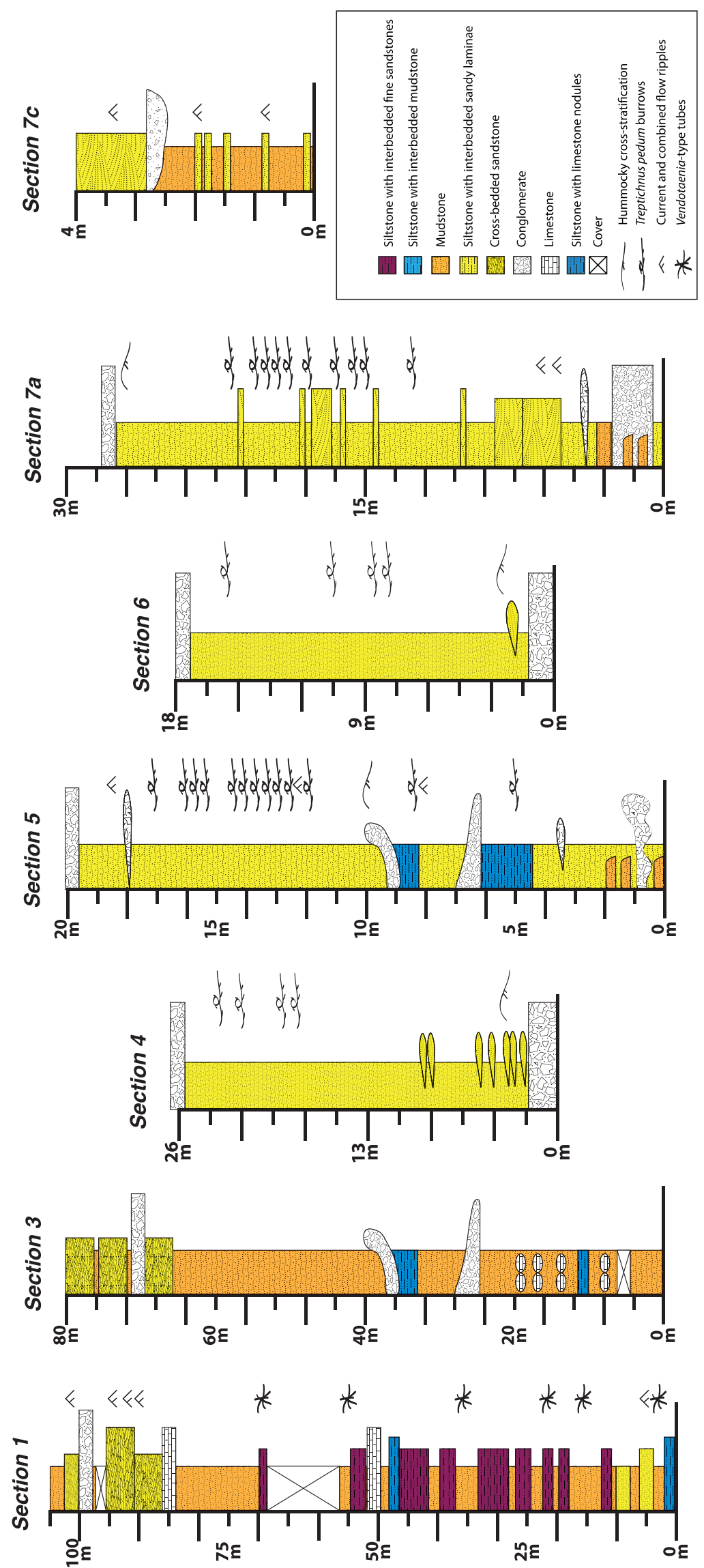

FIGURE 7-Measured stratigraphic sections from Sonntagsbrunn 105. Locations are indicated in Figures 2A and 2B. 


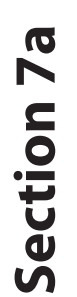
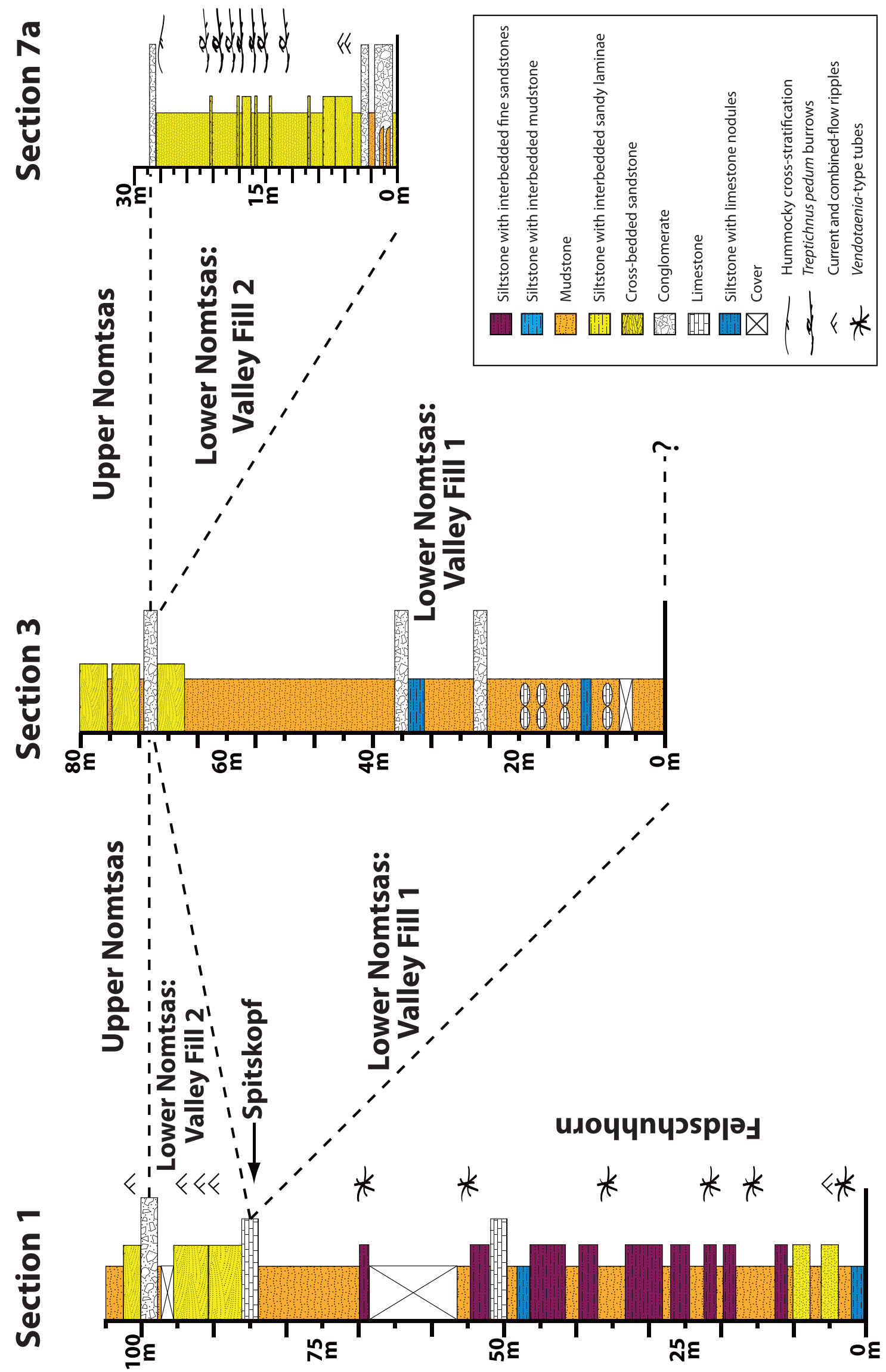

FIGURE 8 -Key sedimentologic relationships from Sonntagsbrunn Farm area. Section numbers as in Figure 2. Y-axis scales are the same between each measured section. Note the relatively limited lateral and vertical extent of Valley Fill 2 strata. 


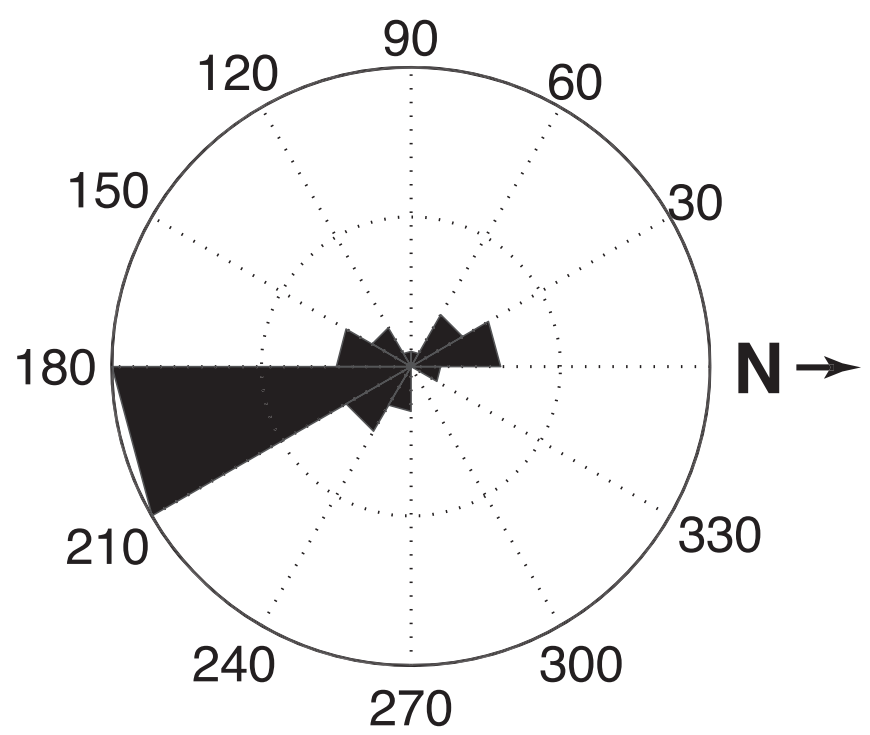

FIGURE 9-Paleocurrent directions from tidally influenced sandstones in the Nomtsas Formation. Number of measurements: 50. Note paleocurrent direction asymmetry.

comparison of VF1- and VF2-bounding surfaces at Sonntagsbrunn and elsewhere could clarify this ambiguity.

Within VF1, there is no evidence for such larger-scale facies trends as shallowing upward, coarsening upward, or other evidence of highstand progradation. The valley fill seems to have been dominated throughout by aggradation of shale and siltstone. It is possible that coarser facies were truncated at the base of VF2. Alternatively, VF1 on Sonntagsbrun 105 may record a relatively sediment-starved environment in which proximal estuaries lacked major river input, at least in this portion of the valley network. Sediment flux would have been high enough to allow accumulation of siltstone and less commonly, fine sandstone, but not so high as to allow advance of sand-dominated shoreface deposits.

The environment represented by the infilling strata of VF1 is regarded as subwave base, with settling from suspension of mud and silt to form the bulk of the sediment volume. Episodically, thin, fine sands were deposited along the valley floor as sediment gravity flow or hyperpycnal flood deposits, likely supplied by rivers entering in the most updip portions of the network (Lamb et al., 2008). The occasional slumping of sandstone beds suggests remobilization on the flanks of the valley.

Basal carbonate-clast conglomerates are interpreted to represent shedding from paleohighs formed of the Spitskopf Member (Figs. 3, 8). Similar conglomerates were observed at the base of the incised valley system observed downdip, at the Swatkloofberg location (Saylor and Grotzinger, 1996). Remote sensing imagery and reconnaissance traverses show a series of paleo-highs (paleo-koppies) to the southwest of Sonntagsbrunn 105, which could be sources for carbonate conglomerates that were shed into the valleys during initial infilling. Once flooded, these highs became less susceptible to erosion, limiting the generation of carbonate detritus. Treptichnus pedum was not observed in any beds from VF1.

\section{Lower Nomtsas Formation: Valley Fill 2 (VF2)}

The majority of the VF2 sequence (sections 4, 5, 6, 7a, 7b, 7c; Figs. 3-6), which postdates VF1, is fine-grained sandstone, siltstone, and shale. Bed thicknesses range from 0.15 to $0.7 \mathrm{~mm}$. Fine-grained sandstone and siltstone are laterally extensive and have parallel lamination, unidirectional current ripples, and show evidence of sediment binding, possibly through the involvement of benthic microbial mats. Interbedded, more thickly bedded sandstone exhibits basal scour and trough cross-bedding. At the base of Valley Fill 2, there is a coarse, matrix-supported, poorly sorted, carbonate-clast conglomerate with strongly lenticular geometry. Conglomerates are overlain by massive, turbiditic sandstones with axially directed paleocurrents (Figs. 8-9). Both conglomerates and overlying sandstones can be seen to onlap the margins of the incised valley (Fig. 19).

Fine-grained, laminated to thin-bedded sandstone also preserves trace fossils of $T$. pedum. The degree of bioturbation is highly variable, from nearly absent (ichnofabric index (ii) 1 of Droser and Bottjer, 1986) to completely bioturbated, mottled strata (ii 5).

We interpret this depositional environment as lower shoreface, just above SWB at its deepest, and tide-influenced on the basis of bidirectional paleocurrents and the presence of trough cross-bedding, based on sedimentary structures, including flaser to lenticular bedding and unidirectional current ripples (Fig. 9). Fine-grained sandstone with mud drapes was probably deposited by waning flows following storm or tidal flows, as described by Saylor (2003). These mud drapes are where the majority of $T$. pedum trace fossils were found.

\section{Upper Nomtsas Formation}

A capping sandstone unit at Sonntagsbrunn (sections 1, 3, and 5; Figs. 3-6) comprises the final valley filling unit, overtops the intravalley highs, and forms a regionally extensive sheet deposit. The intravalley highs effectively define a transgressive ravinement surface; capping sandstones are deposited above this surface. This sandstone is pale cream-colored, fine- to medium-grained, and defines the top of the present-day canyon walls. The sandstone contains abundant current ripples, trough cross-bedding, herringbone cross-bedding, and scour and tool marks (Fig. 16). Some of the beds show basal scour troughs infilled by carbonate breccias and mud-chip breccias. Sandstone beds may be amalgamated or separated by thin recessive micaceous siltstones, interpreted to have been deposited during waning currents. At the base of the upper Nomtsas Formation there is a clast-supported, semi-stratified carbonate conglomerate interbedded with sandstones, distinguishing it from other siltstone/shale-bounded conglomerates at stratigraphically lower positions in the valley fills.

We interpret the capping sandstone to have formed in a high-energy upper shoreface regime; sheet-like bed geometry signifies unconfined, post-valley flows, but with current velocities high enough to form upper plane bed stratification. Tidal currents had a strong influence on the seafloor, as shown by the presence of herringbone cross-bedding, ubiquitous trough cross-bedding, and presence of multimodal paleocurrent directions (Fig. 9).

\section{PALEONTOLOGY}

Treptichnus pedum is used here in the broad sense of Seilacher (2007) to include straight, sinusoidal, curved, or looping burrows constructed from upward-curving segments. The cumulative effect is of a burrow with a largely uniform horizontal base, from which emanate vertical or oblique projections, each of which appears to have communicated with the sediment surface. Recent compilations of $T$. pedum occurrences are provided by Geyer and Uchman (1995) and Vannier et al. (2010). The great majority of Treptichnus pedum reports are from lower Cambrian strata, with fewer but still significant occurrences from the middle and upper Cambrian and from Tremadocian-age beds, and even less common reports in younger rocks. These compilations show the environment of deposition of preserving strata to range from shallow marine to deep-sea settings, with a majority in the marine deposits. Geyer (2005) interpreted T. pedum from the upper part of the Nama Group to have been formed by opportunistic producers under environmental stress in shallow marine habitats. MacNaughton and Narbonne (1999) documented occurrences of $T$. pedum in the Mackenzie Mountains, northwestern Canada, from shallow marine 

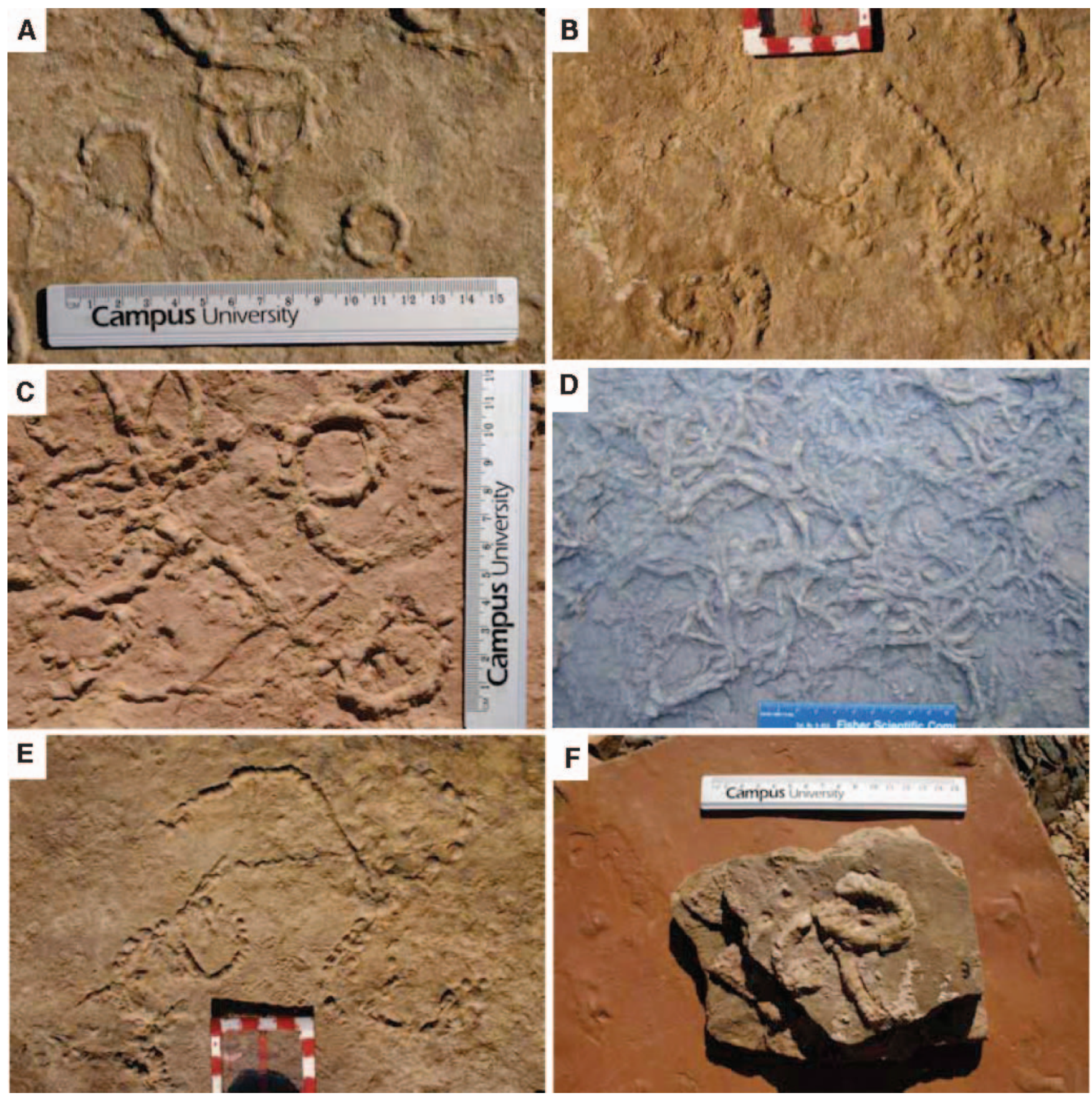

FIGURE 10-Plate of $T$. pedum trace fossil morphology. Scale bar is $\mathrm{cm}$. All images are from soles of beds.

(interdistributary lagoons and mouth bar deposits), fine-grained quartz arenites of lower shoreface deposits, and from the offshore transition and distal shelf. In their study, the greatest diversity of trace fossils was recovered from siltstone and fine-grained quartz arenites deposited between storm and fair-weather base. As a further example, Fillion and Pickerill (1990) recorded T. pedum from prodelta and offshore deposits in the upper Cambrian Bell Island Group, Newfoundland.

\section{T. pedum from the Sonntagsbrunn Sections}

Three-dimensional exposures and numerous occurrences of T. pedum burrows provide an opportunity to quantify $T$. pedum dimensions. A total of 47 length and 61 width measurements were made on burrows preserved in samples observed at the Visionarium site (Figs. 10-15). By measuring these burrows and using burrow width as a proxy for the width of the organism, we were able to estimate the organism's width as $0.5 \pm 0.3 \mathrm{~cm}$ (Fig. 17). We also observed examples of $0.5 \mathrm{~cm}$ burrows that cut themselves off (Figs. 10-12). The lengths of these cutoffs constrain the maximum length of the $T$. pedum organism to $<6 \mathrm{~cm}$.

Trace fossils from Sonntagsbrunn 105 provide a good sample of the morphological diversity of $T$. pedum. Where the burrow is straight, the vertical segments generally are aligned (Fig. 12C). In curved portions of the burrow the segments generally project outwards, resulting in an appearance that has been compared to a crosier (Figs. 12A, B, 13A, B, C). The basal communication between the vertical portions of the burrow is not often preserved, resulting in the appearance of isolated pods of sediment (Fig. 12F). Examination of the full range of material shows that a large range of morphologies results from taphonomic variability (Figs. 12C, D). The vertical segments may be closely spaced, truncating the preceding segment (Fig. 12B), and thereby giving the 

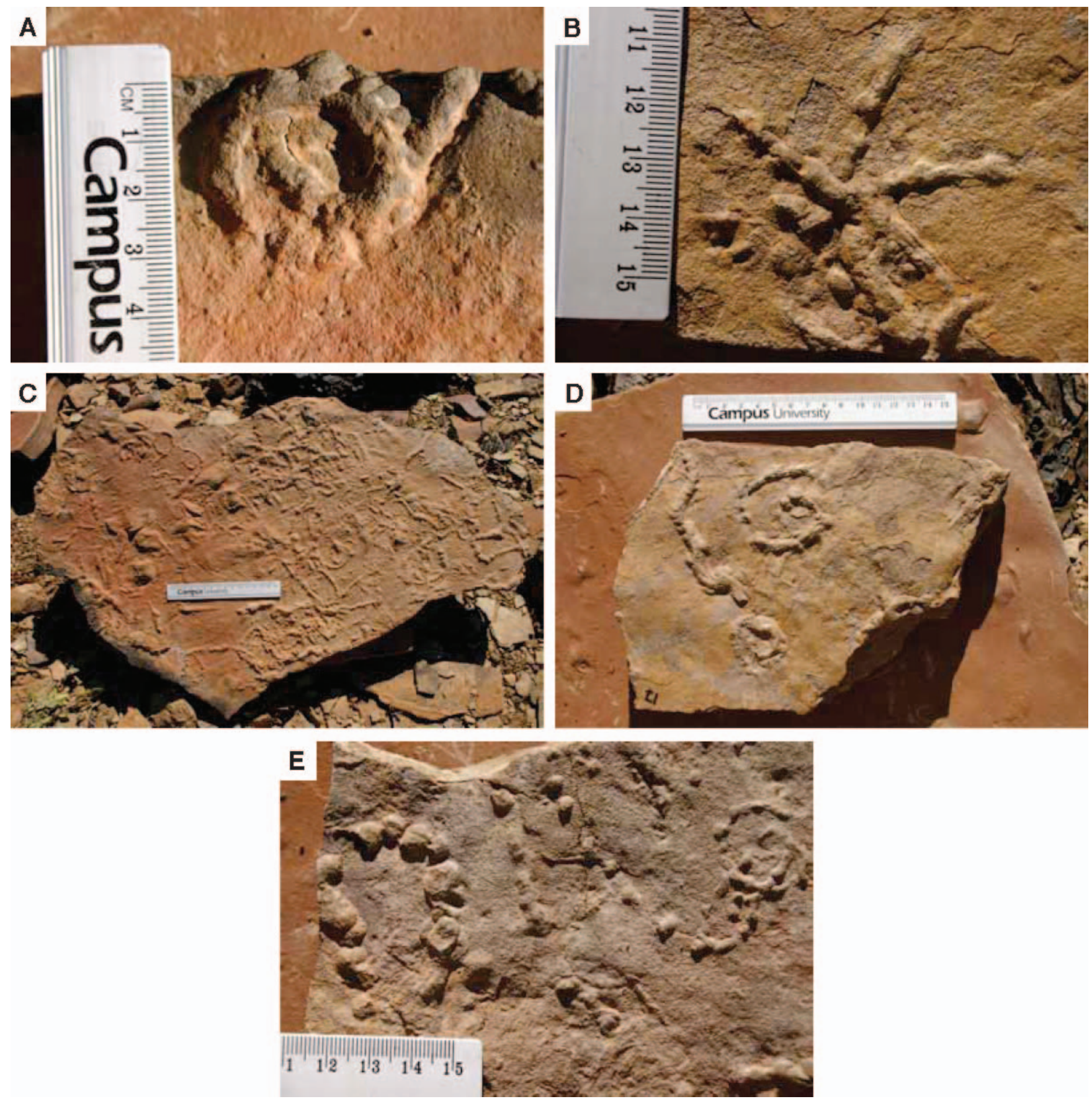

FIGURE 11-Plate of T. pedum trace fossil morphology. Scale bar is $\mathrm{cm}$. A) Smaller traces, although less common at Sonntagsbrunn, exhibit the same morphology as the larger traces, but at $1 / 3$ the scale; this could be a juvenile form of the organism, or an entirely different organism. B) Note three-lobed basal surface on lower right (compare with Fig. 14). C) Bedding surface showing abundance of Treptichnus pedum traces. D) Smaller surface showing burrow cutoff. E) Vertical burrows showing size difference in burrow diameter.

false appearance of a meniscate fill. In some cases, however, successive segments are more widely separated (Fig. 13B). There are also specimens in which the segments show a zigzag arrangement (upper part of Fig. 13C).

Treptichnus pedum of different sizes are commonly found on the same bedding plane (Figs. 12C, E, G), though the width of the vertical elements may be exaggerated by compaction (Fig. 12G). Segment width along a single burrow does not vary in the material examined.

The base of the burrow may show a more or less well developed longitudinal division into a wide central lobe flanked by narrower lobes. This is most strongly developed on burrows that closely follow the base of a bed (Figs. 14B, C, E, G) but is also seen in material that is more clearly part of common $T$. pedum morphologies (Fig. 13F). The lateral lobes may show dentations (Figs. 14B, C, G). When preserved on the upper surface of a sandstone bed, the morphology is dominated by a groove with lateral ridges with less obvious signs of probes (Fig. 15).

In the Sonntagsbrunn sections, T. pedum is common in heterolithic bedding of the second valley fill. Most of these burrows were made within muddy sediment drapes and filled with sandy material, either during construction of the burrow or during later sedimentation (Fig. 16). This taphonomic mode commonly yields the best-preserved 

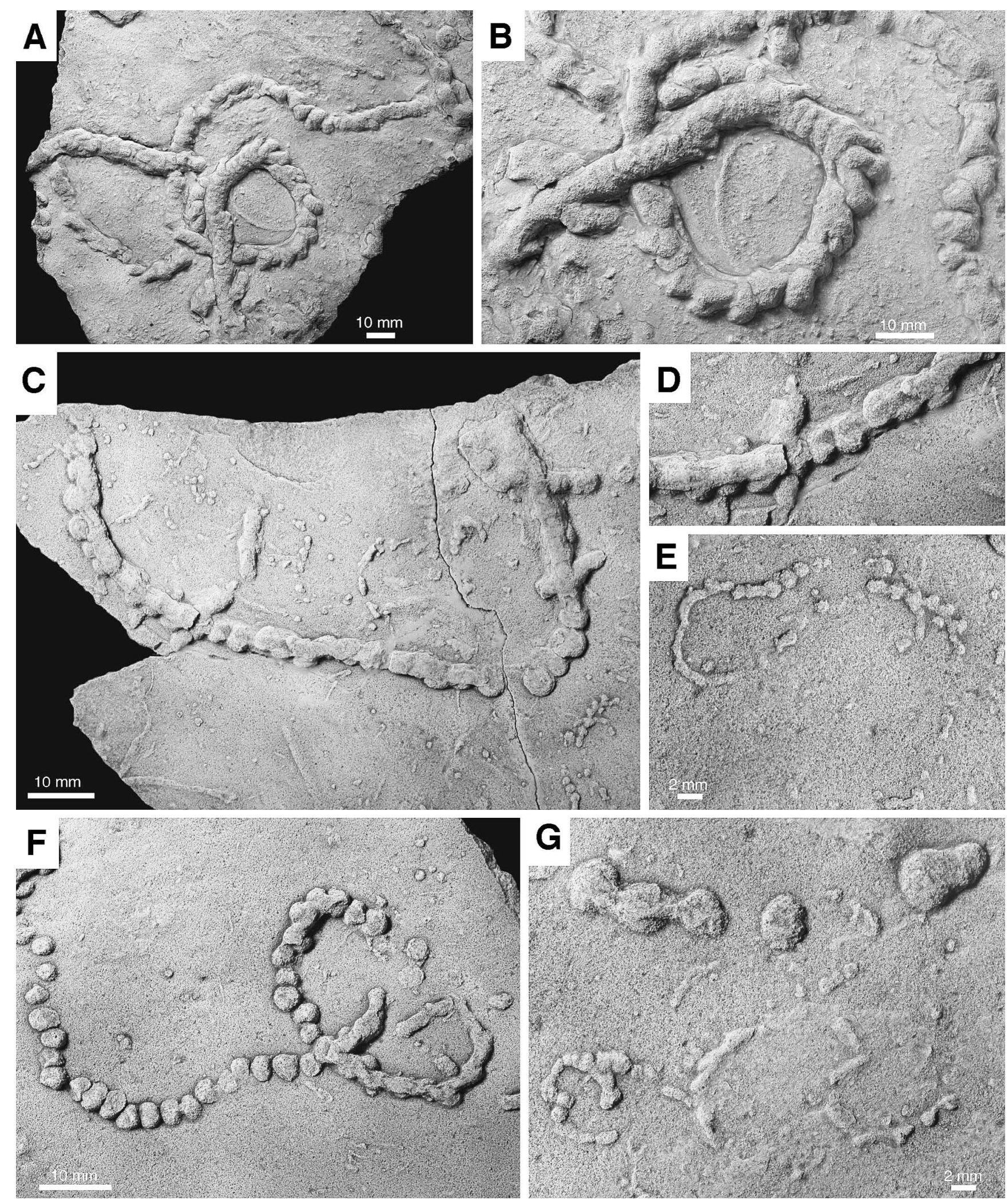

FIGURE 12-Treptichnus pedum preserved on sandstone bed soles. A-B) Specimen with curved portions in which the segments project outwards, resulting in an appearance that has been compared to a crosier. C, D, F) Specimens in which vertically oriented portions are preferentially preserved. E) Close-up of small specimen in lower right portion of image C. G) Two different-sized specimens. Note, however, the thin burrow connecting vertical portions in the larger specimen, which suggests that the width of the vertical portions may have little bearing on the diameter of the producer. 

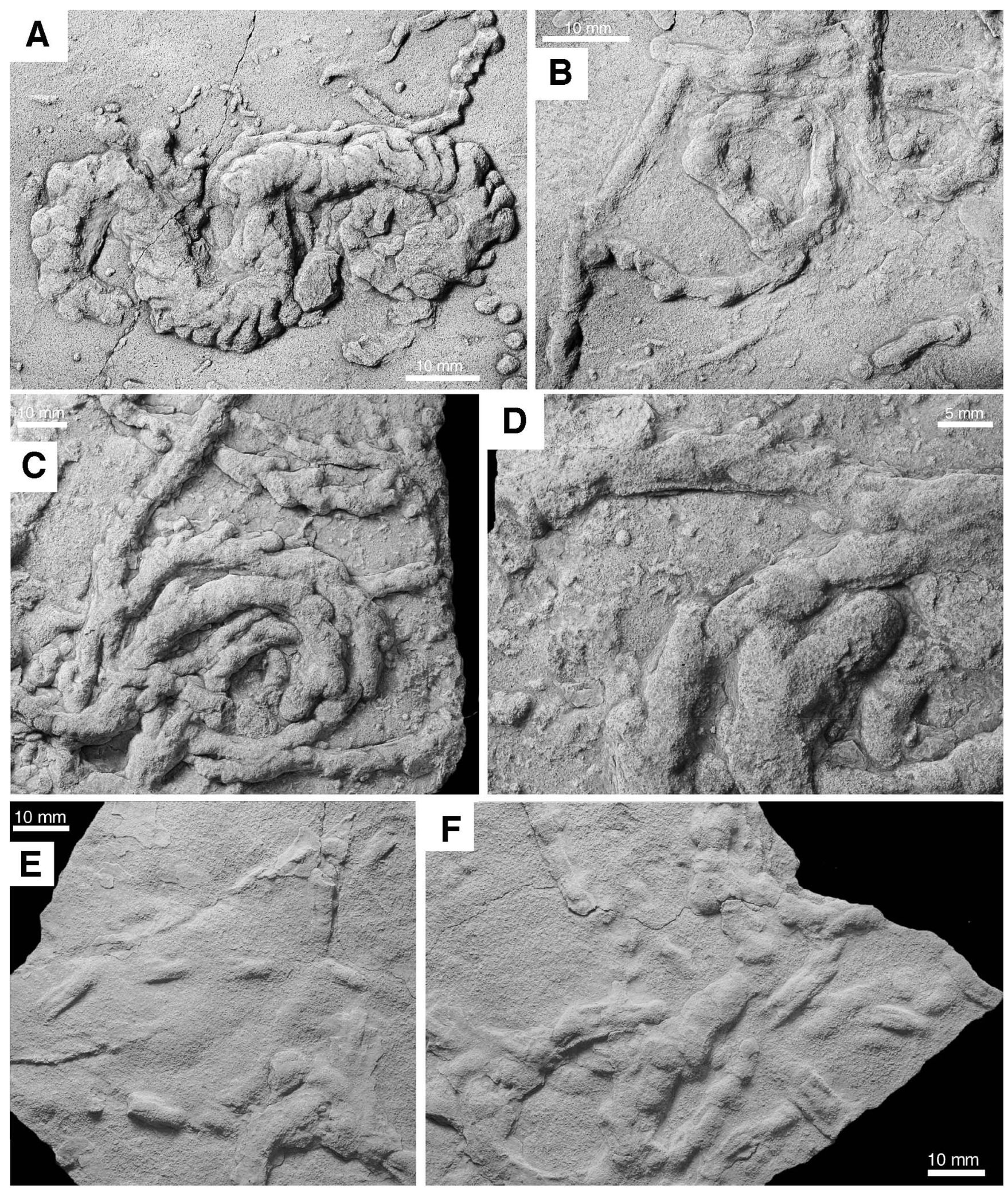

FIGURE 13-Treptichnus pedum preserved on sandstone bed soles. A-D) Curved specimens showing differences in the spacing of vertical probes. Note zigzag development of burrow in upper part of C. E-F) Specimens largely preserved as disjunct probes, in places showing a three-lobed basal surface.

material. Other traces were at least partly made within sandy beds. The absence of $T$. pedum from the first valley fill of the Nomtsas Formation suggests that the producers of $T$. pedum did not inhabit the deeper-water environment. In contrast, the absence of $T$. pedum from the high-energy sandier facies of the upper Nomtsas Formation could be because highenergy settings tend to preserve only deeper-tier biogenic structures (unlike the shallow-tier $T$. pedum). Bedding soles in this facies are dominated by erosional sedimentary structures that would have eroded 

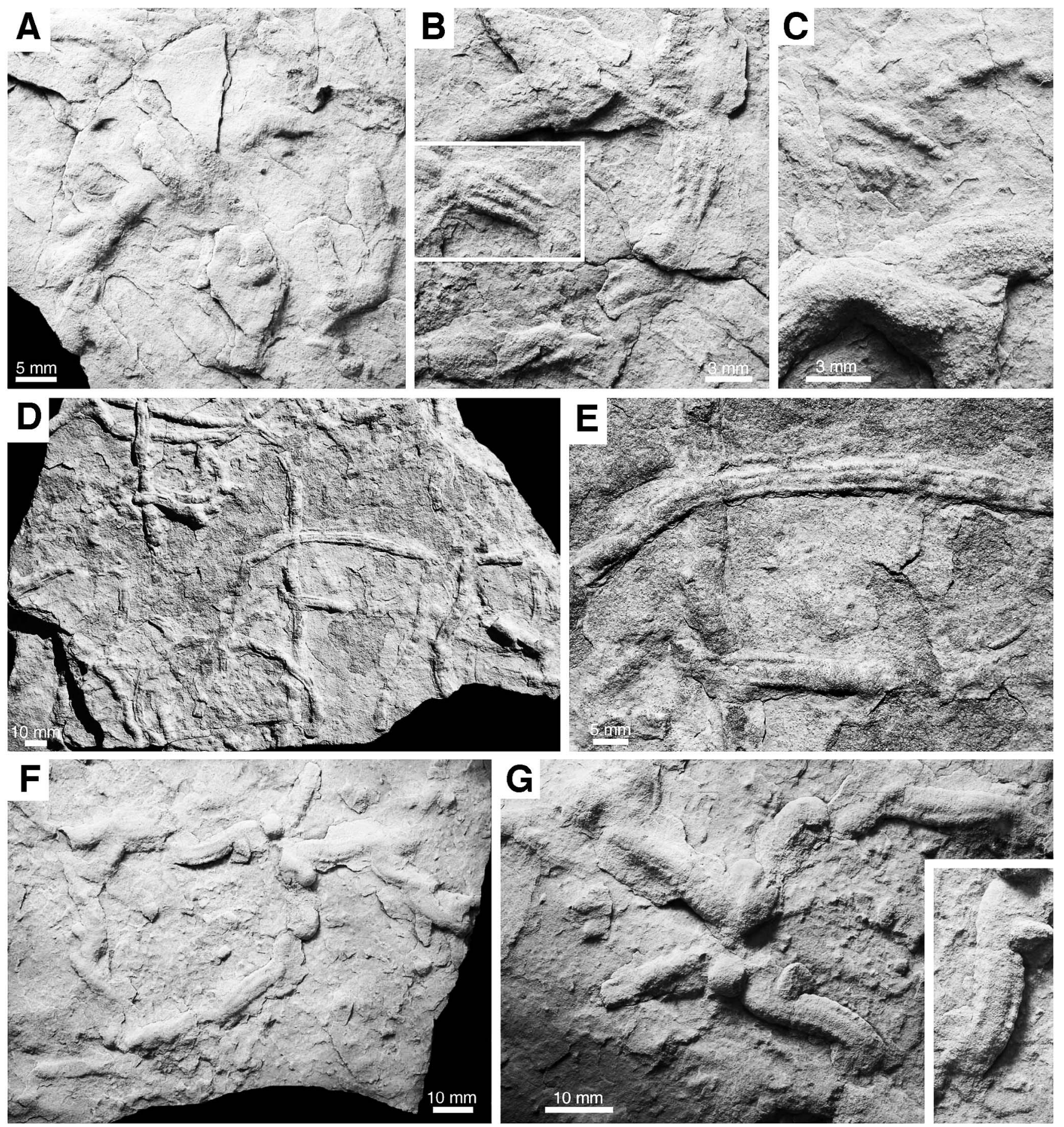

FIGURE 14-Treptichnus pedum preserved on sandstone bed soles, with examples of specimens with a three-lobed basal surface and narrow lateral lobes with a fine transverse ornamentation. E is a close-up of central area in D. G shows burrow segments in upper part of $\mathrm{F}$ with a different orientation (rotated $180^{\circ}$ ). Insets in B and $\mathrm{G}$ are highlighted details.

T. pedum structures were they produced in this setting. Indeed, some slabs show what may be remnants of strongly washed-out trace fossils (Fig. 15). The depositional setting represented by the second valley fill was obviously hospitable to the producer of this trace fossil.

\section{DISCUSSION}

Biostratigraphy

A pronounced carbon isotopic anomaly (Bartley et al., 1998; Amthor et al., 2003; Maloof et al., 2010), small shelly fossils (e.g., Mis- sarzhevsky, 1989; Qian and Bengtson, 1989), and organic-walled microfossils (Moczydlowska, 1991) have all been used to located the ECB regionally, but none of these markers are available in southeastern Newfoundland, where the ECB is defined globally.

Since the GSSP was defined, T. pedum has been found in beds a few meters below the ECB boundary in Newfoundland (Gehling et al., 2001), and traces of comparable complexity have been described from uppermost Ediacaran sandstones in Namibia (Geyer and Uchman, 1995; Jensen et al., 2000; Jensen and Runnegar, 2005), reducing the precision of trace-fossil-based correlations to the GSSP as a 

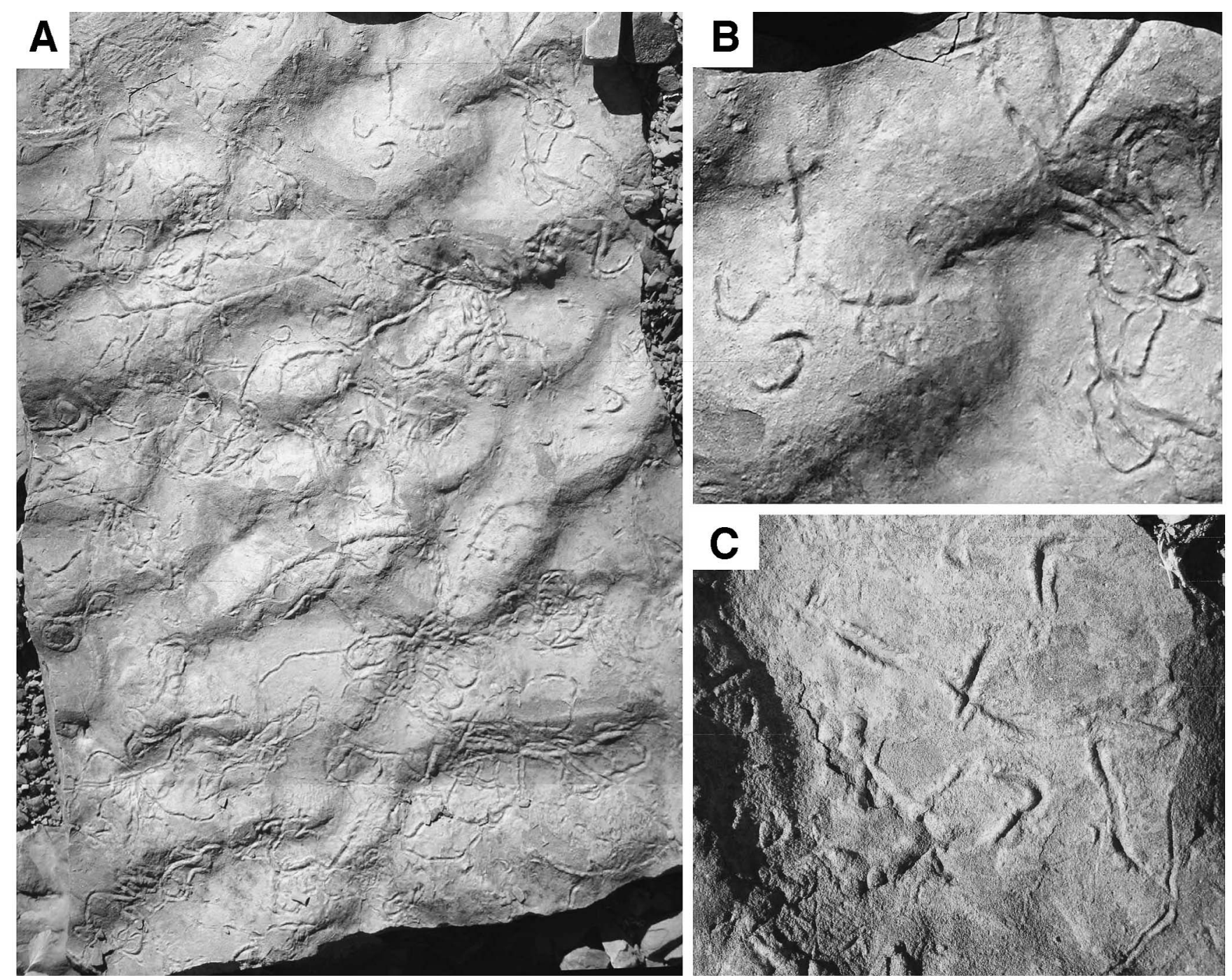

FIGURE 15-A-C) Top surface of sandstone bed covered with Treptichnus pedum preserved as grooves. B is a close-up of top area in A. Hammerhead in A is $24 \mathrm{~mm}$ wide. Furrows in $\mathrm{C}$ are about $5 \mathrm{~mm}$ wide.

consequence of abrupt facies changes in the type locality (Myrow and Hiscott, 1991, 1993).

A greater limitation, however, may be the distribution of facies favorable for development and or preservation of $T$. pedum. To date, only limited information has been published on the environmental distribution of these traces. Faulting in Newfoundland, which can scramble context and range constraints, and abundant carbonates in Namibia (an unfavorable lithology for $T$. pedum) limit the capacity to resolve this distribution in these two locations.

Within the Chapel Island Formation in Newfoundland, Member 1 preserves a number of traces assignable to Treptichnus sp. and T. pedum in close proximity to desiccation and synaeresis cracks (Gehling et al., 2001, p. 214). Whereas accepted T. pedum specimens above the ECB are found within sediments described as alternating fine- to mediumgrained sandstone, trace fossils below the boundary occur in alternating beds of siltstone and medium-grained sandstone (Myrow, 1987; Gehling et al., 2001, fig. 1). Two reports of sedimentary structures within strata, including synaeresis cracks and current ripples, bear on the paleoenvironmental locus of these trace fossils (Gehling et al., 2001, fig. 1). Facies changes at the GSSP in Newfoundland have led others to suggest that $T$. pedum could have ranged below the GSSP (Gehling et al., 2001, p. 216).

Limited populations of treptichnids are known from a siliciclastic interval of the Huns Member (Nasep Member sensu Germs) at Arimas
Farm (Germs, 1972; Jensen et al., 2000). These are similar to the varieties of $T$. pedum observed from the Nomtsas Formation, including the presence of a three-lobed basal surface (cf. Fig. 13E). Geyer and Uchman (1995, p. 191) described material having the overall morphology of $T$. pedum from the Nasep Member at Holoog Farm 106. Further discoveries or descriptions of these pre-Nomtsas Formation treptichnids are needed to establish if they represent preservational end members of otherwise identical trace fossils or if they record a simpler morphology (Jensen et al., 2000). Additionally, the Spitskopf Member of the Urusis Formation has yielded the trace fossil Streptichnus narbonnei that is of comparable complexity to $T$. pedum (Jensen and Runnegar, 2005). Treptichnus pedum has also been reported to occur in Ediacaran strata in the Vahnrhynsdorp Group of South Africa (Seilacher, 2007), but the age of this succession is poorly known (Aceñolaza et al., 2009).

ECB sections at Sonntagsbrunn Farm 105 contain two superimposed incised valley deposits assigned to the Cambrian Nomtsas Formation (Figs. 3, 8). The strata in these valleys contain a wide range of sedimentary facies deposited across a range of environments, from just above SWB (Figs. 18C, D) to tidally influenced sandstones and shoreface sandstones (Figs. 18E, F). Despite this, T. pedum trace fossils only occur within the upper incised valley deposit, VF2 (Fig. 16).

The confined occurrence of $T$. pedum to VF2 could reflect one of two possibilities. First, the evolution and first appearance of the T. pedum 

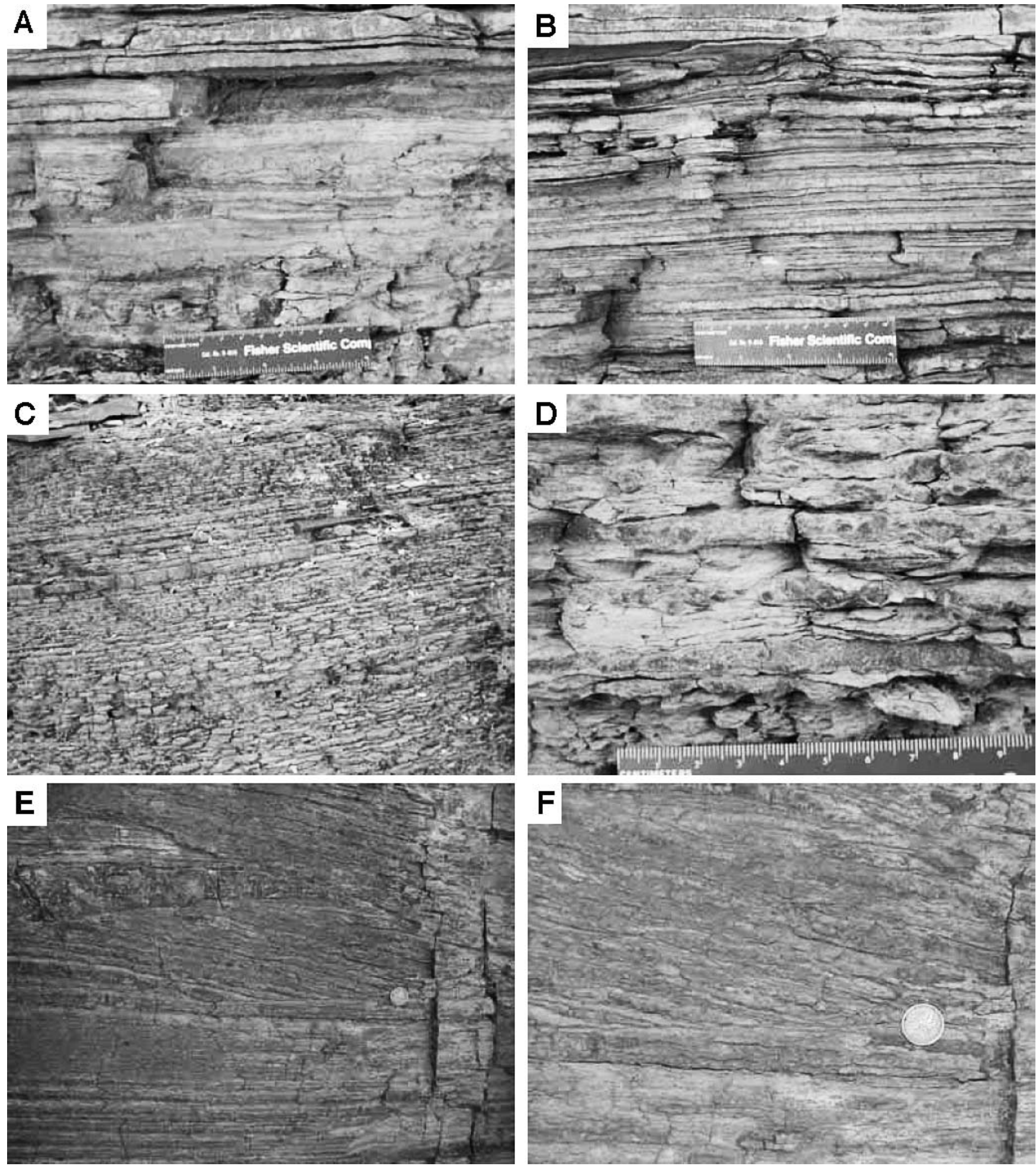

FIGURE 16-Plate of T. pedum-bearing strata. A) Close-up of recessive mudstones within lower portion of Valley Fill 2. B) Close-up of siltstones within lower portion of Valley Fill 2. C) T. pedum-rich unit. D) Close-up of cross section of T. pedum beds. E) Cross-bedded, tidally influenced siltstones with $T$. pedum trace fossils in foresets. F) Closeup of E. Note circular cross sections of T. pedum traces.

organism in the stratigraphic record, or second, taphonomic bias associated with nonuniform preservation of facies and environmental control on the distribution of $T$. pedum first occurrences. Several reasons support the second hypothesis over the first.

Previous workers described a somewhat limited occurrence of Treptichnus within the underlying Huns Member (Jensen et al., 2000). The structures described are similar in form to the trace fossils observed here, and are found in siliclastic strata with a somewhat similar depositional environment-shallow marine, with current and wave structures present); however, the complex interaction of thrust faults and incised valleys at Arimas Farm 83 complicates stratigraphic placement. If these reports are correctly located stratigraphically, then the first appearance of these organisms in southern Namibia predates the younger, but more widespread, occurrences reported here. This 

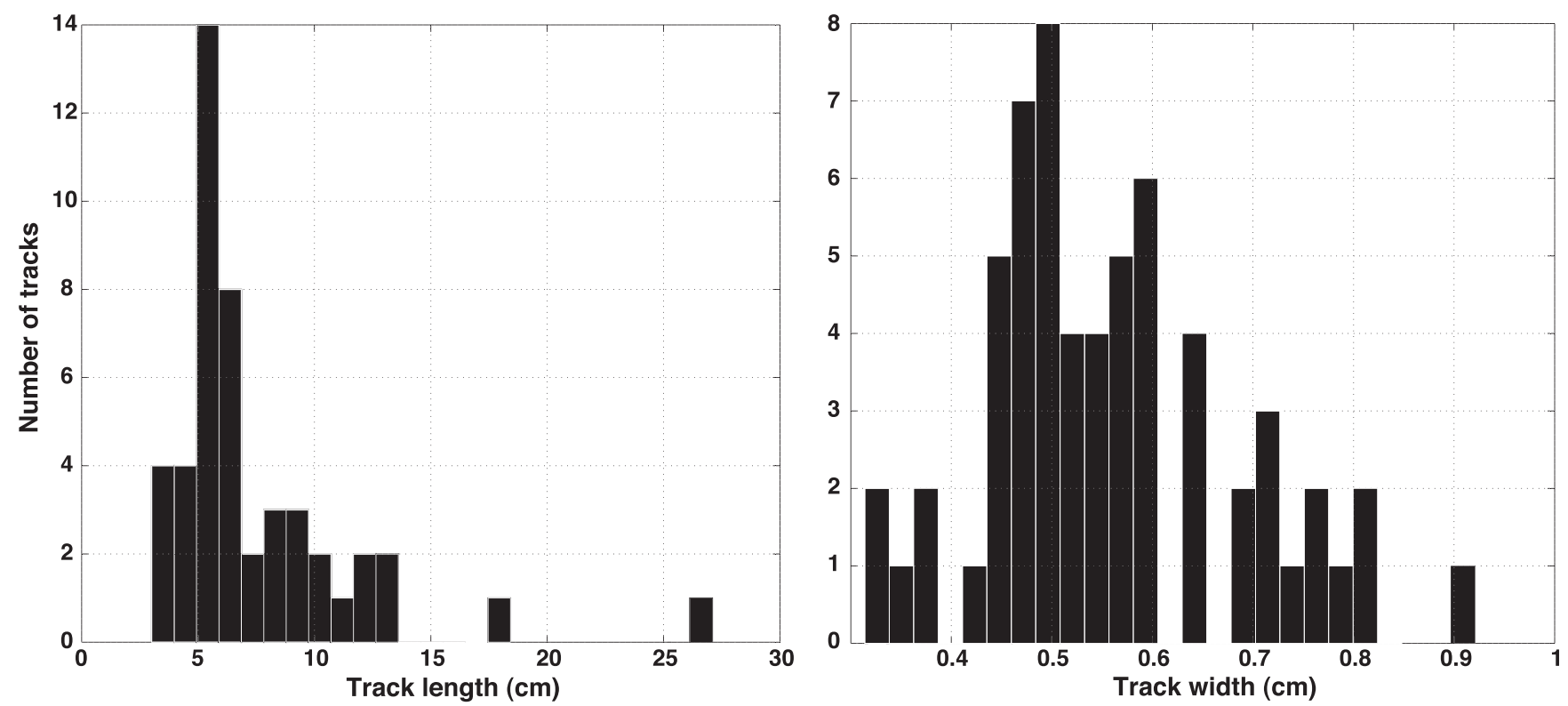

FIGURE 17-Histograms of T. pedum trace length and width. Note that with a large enough sample size, there appears to be a continuous distribution of burrow widths, from approximately $0.35 \mathrm{~cm}$ to over $0.9 \mathrm{~cm}$, suggesting a single population with slight variation in size. Mean track length is $7.49 \mathrm{~cm}$, mean track width is $0.56 \mathrm{~cm}$.

would imply that the spectacular occurrences of $T$. pedum at Sonntagsbrunn 105 are controlled by environment and taphonomy, rather than evolutionary first appearance.

In addition, available geochronologic constraints suggest that the valley filling deposits postdate the ECB. Outcrops on Sonntagsbrunn Farm establish that there are two sequences of valley fill events, not simply one base-level drawdown event as observed at more downdip locations (e.g., Swartkloofberg: Grotzinger et al., 1995a; Saylor and Grotzinger, 1996). The younger VF2 event was of lower magnitude than the VF1 event, and thus its downdip equivalent may be represented by an influx of sand, for example, into the VF1 system, rather than rejuvenation of the valley system in that location. Other models of depositional dip variations predict this in incised valley systems (Zaitlin et al., 1994; Talling, 1998).

Views from near section 5 (Figs. 3, 5, 6) illustrate Valley Fill 2 incising into shale and siltstone of Valley Fill 1 (Figs. 20-21). The amount of time elapsed between these valley-filling events is unknown, but strata truncated by the incised valley fill also likely predate the negative carbon isotope excursion correlative with the ECB (Grotzinger et al., 1995a). Furthermore, to the west of the study area, an ash bed dated to 539 Ma occurs at the base of the valley fill deposit at Swartkloofberg (Grotzinger et al., 1995a). Whether the single valley fill seen in downdip locations correlates in time to VF1, VF2, or both, it strongly suggests that the first appearance of $T$. pedum at Sonntagsbrunn Farm is at most $539 \mathrm{Ma}$ (Fig. 21). Therefore, it is likely that the first appearance of the trace fossil $T$. pedum significantly postdates the Ediacaran-Cambrian boundary in southern Namibia.

This leads us to favor an interpretation of taphonomic or environmental control on distribution of $T$. pedum. Given the broad range of depositional environments in the two valley fill successions preserved at Sonntagsbrunn, and the restriction of trace fossils to one particular environment, our work suggests that the organism that created the $T$. pedum traces preferred tidally influenced shallow marine environments. If correct, these observations urge caution in using the first appearance of $T$. pedum in a given locality as marker for the ECB.

This interpretation supports initial work (Grotzinger et al., 1995a) in placing the ECB within the hiatus between the Schwarzrand and Fish River subgroups. This attribution is based on paleobiological, biogeochemical, and radiometric data from several continents that link the boundary to a transition from skeletons of distinctly Ediacaran aspect (e.g., Cloudina, Namacalathus) to those characteristic of the Cambrian, a diversification of small spinose acritarchs, and a pronounced negative $\mathrm{C}$-isotopic excursion, all dated at $542 \pm 1 \mathrm{Ma}$. In most sections where $T$. pedum occurs in conjunction with these other markers, it appears above Cloudina/Namaclathus and within or above the carbon isotopic nadir. In contrast, Geyer (2005) places the ECB in Namibia lower in the section, within the Schwarzrand Subgroup, based on the occurrence of treptichnid trace fossils. Boundary placement is, in fact, difficult to resolve because of all the data sources used to correlate ECB successions globally, only $T$. pedum, and associated trace fossils, are available in the GSSP in Newfoundland. Limited C-isotopic data from organic carbon suggest that the negative $\mathrm{C}$-isotopic excursion may occur above the GSSP in Newfoundland (Strauss et al., 1992), but resolution of this issue awaits further work.

In a formal sense, alternative boundary placements in Namibia are difficult to confirm or refute. What available data do make clear, however, is that the first appearance of treptichnids, sensu lato, in Namibia predates the appearance of T. pedum in sections from Siberia, Poland, and northwestern Canada, whereas the first appearance of $T$. pedum sensu stricto in Nomtsas VF2 postdates first appearances in other well-studied regions - very likely by several million years. This underscores the complicating effects of environmental preference and taphonomic circumstance on the use of $T$. pedum to draw boundary correlations.

\section{Paleobiology}

Various hypotheses have been proposed for the organisms and behavior that led to Treptichnus pedum burrows. The most common interpretation has been of deposit feeding in which sediment was processed during the production of the burrow system (e.g., Seilacher, 1955; Geyer and Uchman, 1995). One potential issue with this interpretation is that there is no clear evidence for sediment manipulation, such as meniscate fill, and that the burrows appear to have been open and passively filled with sediment. An alternative proposal is that the burrow system was for protection and dwelling and that feeding took place on the sediment surface (Jensen, 1997; Dzik, 2005). Vannier et al. (2010) suggested that T. pedum implies predation or scavenging on the basis of observations of modern priapulids. Another hypothesis suggested by Seilacher (2007, p. 182) is that an 

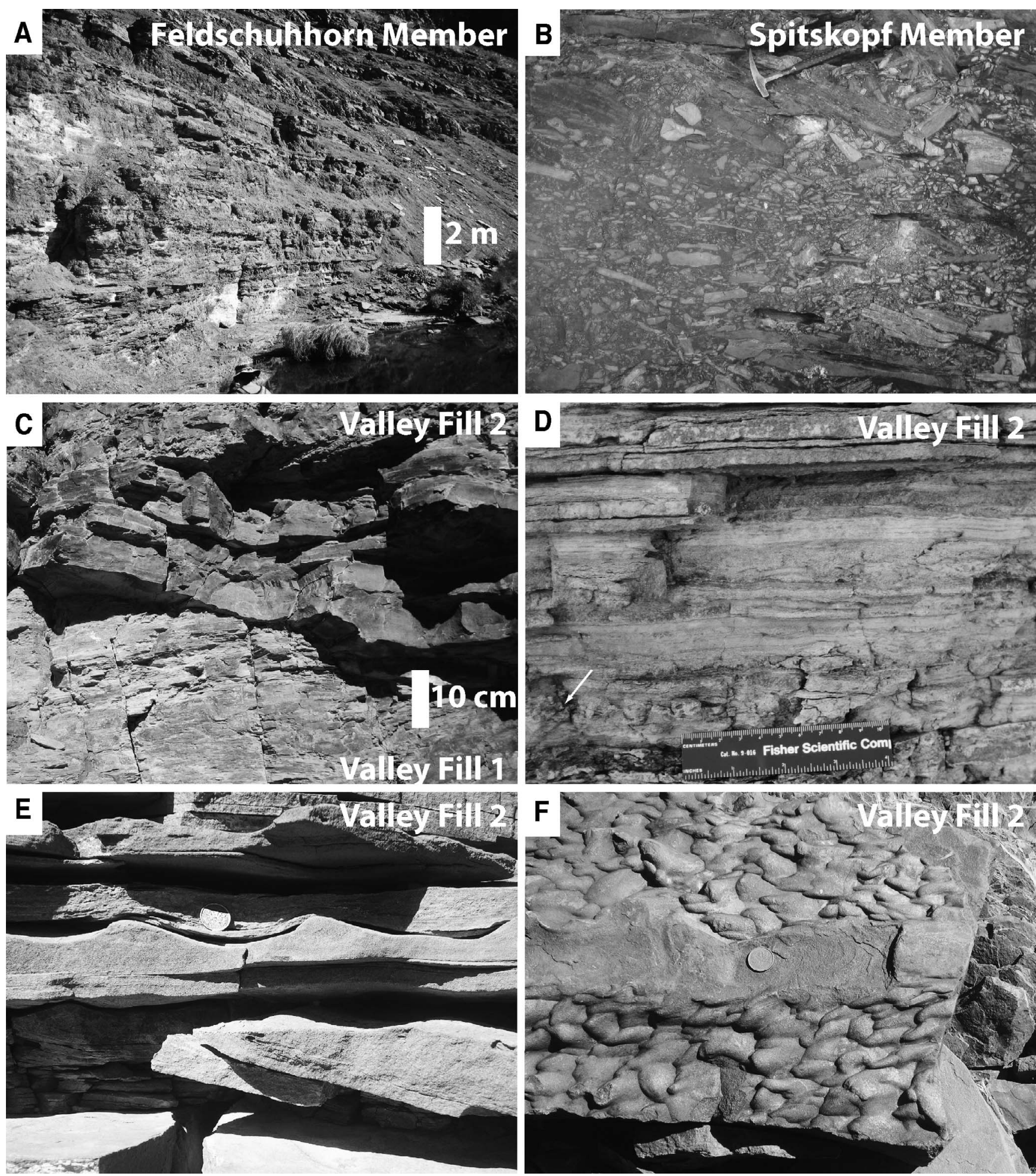

FIGURE 18-Sedimentary features and structures found on Sonntagsbrunn Farm. A) Outcrop of Feldschuhhorn Member from measured section 8. Note the white-weathering shales. B) Carbonate-clast conglomerate from Spitskopf Member. Note tabular clasts suggesting minimal transport. C) Fissile shales from Valley Fill 1 cut by medium-grained siltstones of Valley Fill 2. D) Mudstone drapes and siltstone-sandstone interbeds from Valley Fill 2. Arrow indicates cross section of T. pedum burrow. E) Unidirectional current ripples from upper portion of Valley Fill 2. F) Tool marks from base of bed in upper portion of Valley Fill 2.

undermat miner closely following a thin sand layer made $T$. pedum; he further suggested that straight varieties show a response to paleocurrents. No clear evolutionary trends in the morphology of T. pedum have been recorded (Seilacher, 2007). Neto de Carvalho (2008), however, reporting on $T$. pedum from the deep-water Devonian Terena Formation of Portugal, suggested that a pattern of onshore-offshore displacement recorded in many trace fossils could apply also to this type of trace fossil. These traces bear great similarity to burrows that have been variously assigned to Hormosiroidea or Ctenopholeus. Fürsich et al. (2006) interpreted Ctenopholeus kutcheri (lower Cambrian, Jurassic) as an open burrow system that functioned to trap small motile organisms. T. pedum has a cosmopolitan distribution and long 

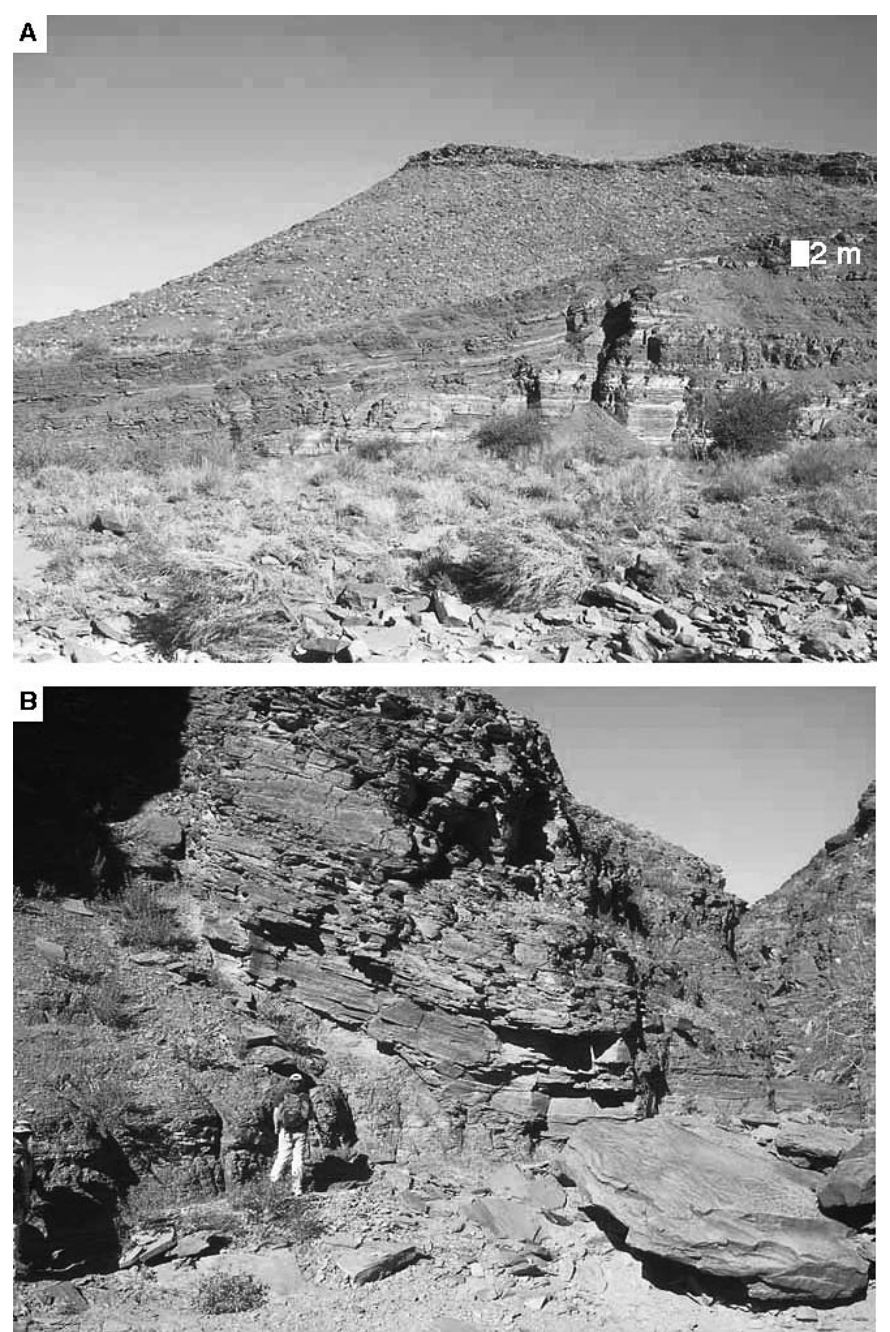

FIGURE 19-Outcrop-scale onlap of valley fill deposits. A) Onlap of Valley Fill 1 relative to Feldschuhhorn Member shales, inset from Figure 3. B) Onlap of Valley Fill 2 on Valley Fill 1 shales.

stratigraphic range. Over this time and space $T$. pedum must have been made by different producers and may include more than one type of behavior. Biological interpretation, therefore, might usefully be discussed on a case-by-case basis.

By definition, T. pedum is the earliest Cambrian animal trace fossil (Brasier et al., 1994). That similar traces may actually occur somewhat earlier in Newfoundland and Namibia only reinforces the status of Treptichnus pedum as the oldest evidence for animals that combine morphological and behavioral complexity. There is general agreement that the T. pedum tracemaker was a motile bilaterian animal that lived below the sediment-water interface, propelling itself forward in upwardcurving projections that breached the sediment surface (Seilacher, 1955; Seilacher and Hemleben, 1966; Geyer and Uchman, 1995; Jensen, 1997; Dzik, 2005). Accepting this, T. pedum's functional biology might be interpreted in two distinct ways. The T. pedum animal might have lived infaunally to avoid predation or desiccation, surfacing episodically to feed and obtain oxygen. Alternatively, the animal might have been a sediment feeder that surfaced regularly to exchange gases and perhaps to disperse eggs, sperm, or fertilized eggs. The restriction of Namibian T. pedum populations to environments where subaerial exposure was not a chronic challenge suggests that protection from adverse physical conditions was not a primary function of the burrow.

Priapulids, an invertebrate phylum with a prominent Cambrian fossil record, are most commonly suggested as producers of this type of trace fossil. Orlowski and Zylinska (1996) documented surface sculpture on Polish material of the middle and late Cambrian Treptichnus rectangularis that they attributed to terminal spines in Cambrian priapulids. On this basis, and noting points of comparison to Cambrian body fossils, Dzik (2005) argued that the T. pedum animal was a priapulid worm, a conclusion seconded by Vannier et al. (2010) on the basis of actualistic experiments. Living Priapulis caudatus move through the sediment surface by extending their anterior proboscis, anchoring it to the substrate, and then pulling the rest of the body forward. The worms change direction constantly, generating a lobed trackway in which successive finger-like projections are offset by $\sim 30$ degrees. The resulting track bears comparison to T. pedum in two dimensions, although it does not have $T$. pedum's three-dimensional complexity (Vannier et al., 2010). For this reason, Vannier et al. (2010) concluded that the Cambrian T. pedum animal could have been a stem group bilaterian with anatomical complexity comparable to that of modern priapulids, rather than a priapulid per se. While there is ample data on the burrowing mechanism of modern priapulids, very little is known about the type of burrows they construct. The only available data is from Halicryptus spinulosus, which form relatively deep vertical burrow systems (Powilleit et al., 1994) that bear little resemblance to $T$. pedum.

Building on the priapulid analogy, Vannier et al. (2010) interpreted the $T$. pedum animal functionally as a predator on small invertebrates. Most modern priapulids prey on other small animals in the sediment, but a few feed on organic debris and at least one, Maccabeus tentaculatus, is a trap feeder, living in a tube and ensnaring unsuspecting prey (Brusca and Brusca, 1990). The environmental specificity of Namibian T. pedum casts doubt on their interpretation as foraging or trapping predators, although further analysis of Sonntagsbrunn 105 material could shed more light on this problem.

Whether a predator, deposit feeder, or infaunal filter feeder, the $T$. pedum animal must have possessed paired muscles and a hydrostatic skeleton to facilitate movement through the sediment. Living priapulids exchange gases by diffusion across their epidermis, but the Cambrian trace fossils hint that their tracemaker may have had anterior tentacles or other appendages for gas exchange or prey capture (Fig. 14). They certainly had anterior sensory and feeding organs, as well as a welldeveloped gut. Webster et al. (2006) have argued that the slowly evolving priapulids provide our best anatomical and genetic guide to ancestral ecdysozoan biology. Thus, living priapulids may provide broad insights into $T$. pedum biology, even if the specimens of Treptichnus pedum do not offer specific clues to the producers' morphology. The Nomtsas Formation material offers a possible exception in the form of denticle-like protrusions on the lateral lobes in some specimens (Figs. 14B, C, G). Although it cannot be excluded that these relate to the animals' burrowing mechanism, they could reflect differentiation along the ventro-lateral margin of the producer.

As a bilaterian animal, the producer(s) of $T$. pedum must have possessed the array of regulatory gene families common to living bilaterians. Many of the cell adhesion and signaling genes that play important roles in bilaterian development occur deeper within the opisthokont tree, even in single-celled sister groups of the metazoans (King et al., 2008; Sebè-Pedrós et al., 2010; Knoll, 2011). With that in mind, comparative genomics indicates that a great deal of gene network evolution took place along the evolutionary pathway from sponges to eumetazoans (bilaterians and cnidarians), and still more gene duplication defined the path from ancestral eumetazoans to bilaterian animals (Degnan et al., 2009; Srivastava et al., 2010). As reviewed by Erwin (2009), the earliest crown group bilaterians arguably possessed a rich array of transcription factors for developmental regulation, including seven or eight HOX genes for anterior-posterior patterning; eight or more additional ANTP-class genes including ParaHox and NK genes that further specify body organization; dorsal-ventral patterning controlled by the sog/chordin dpp/BMP2/4 system; eye formation 

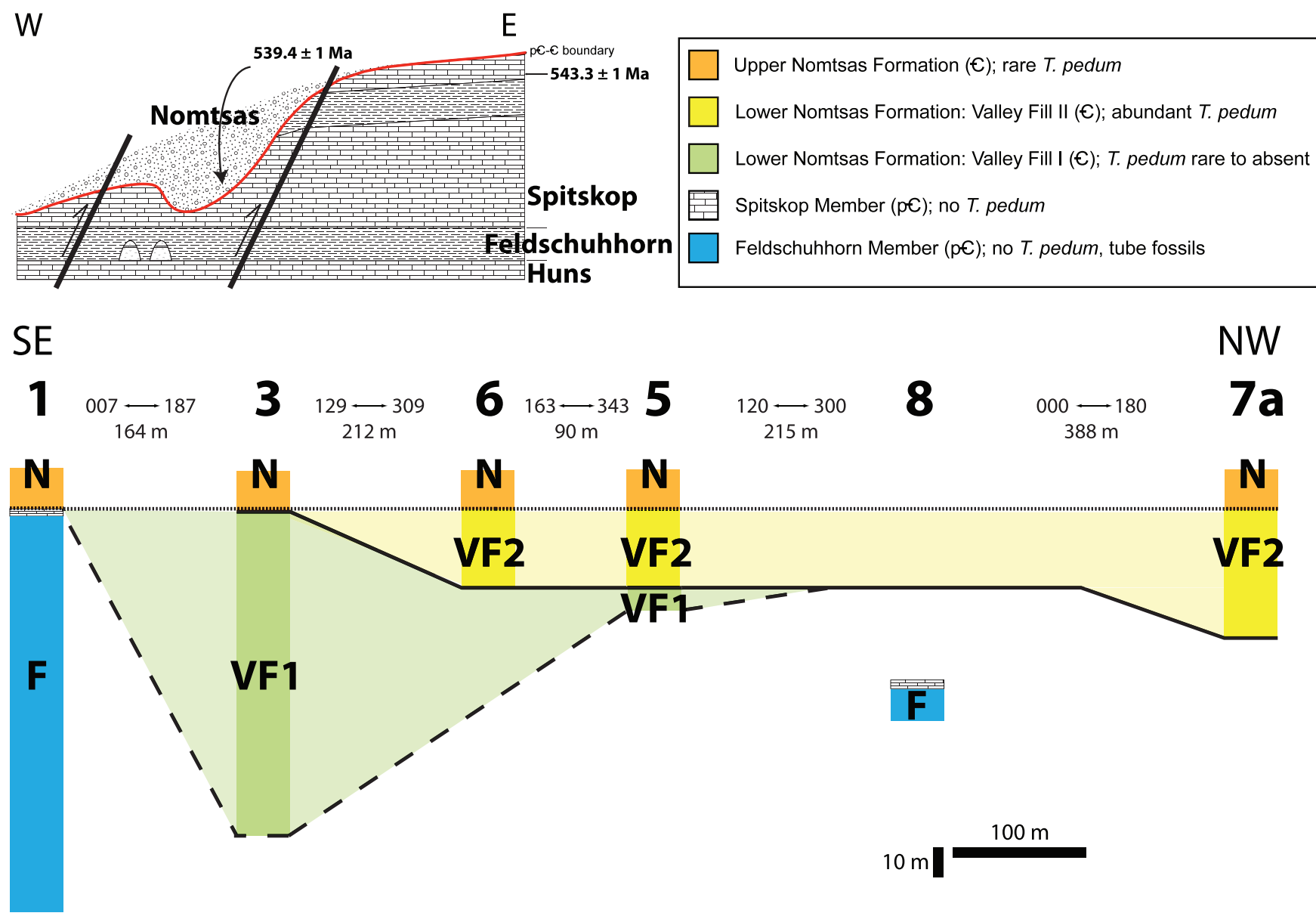

FIGURE 20-Summary of local and regional stratigraphic relationships from Sonntagsbrunn Farm. Top left: regional geologic and stratigraphic interpretation from Saylor and Grotzinger (1996). Below, a transect from the southeast to the northwest of sections on Sonntagsbrunn. Valley Fills 1 and 2 are interpolated between sections; where they are not present in measured section, stratigraphic relationships have been interpolated using outcrop photos.

directed by Pax6 and interacting genes; heart differentiation mediated by Nkx2.5/tinman; and miRNAs that further help to guide development. All of these gene families and more were probably present in the producer of the earliest $T$. pedum, as, by functional interpretation, were Distalless family genes that underpin appendage formation in living bilaterians (Panganiban et al., 1997). Indeed, much of this developmental toolkit was probably assembled earlier, as evidenced the Ediacaran bilaterian Kimberella, found in 555-560 Ma rocks (Fedonkin et al., 2007). Treptichnus pedum, then, reinforces the view that key genetic innovations that made bilaterian diversification possible were largely in place as Cambrian time began.

Behaviorally, T. pedum is characterized by frequent angular offsets to its forward and upward motion, with a directional bias that commonly leads to circular or spiral meanders (Fig. 11). Functionally, such behavior would have worked to keep the $T$. pedum animal within the narrow environmental zone in which foraging was most profitable. Functional inferences suggest that $T$. pedum moved in response to two distinct environmental cues: oxygen and food. The interacting behavioral responses to these cues are widespread in extant organisms and have been studied extensively in the experimental roundworm Caenorhabditis elegans. In C. elegans, two distinct sets of sensory neurons induce the worms to move away from microenvironments with suboptimum oxygen levels: so-called URX sensory neurons are activated by high oxygen, whereas BAG neurons respond to low oxygen levels (both systems employ signaling via cyclic guanosine monophosphate and the neurotransmitter serotonin; Chang et al., 2006; Zimmer et al., 2009). Living priapulids exhibit a pronounced tolerance for low oxygen levels, and $\mathrm{O}_{2}$ would have been a persistent issue for $T$. pedum in muddy sediments. Thus, there is reason to believe that the tracemakers of Nomstas $T$. pedum possessed sensory neural networks broadly comparable to those in living roundworms.

Food cues also stimulate movement, although these can be overridden by the need to maintain optimal oxygen levels (Chang et al., 2006). Notably, C. elegans responds to changing food cues by forward movement, with episodic reorientation-as observed in $T$. pedum. Foraging in C. elegans uses interacting sensory (olfactory) and locomotory neurons, with additional neuronal circuits developing through life to enable such learned responses as food avoidance (Ha et al., 2010).

In summary, then, the $T$. pedum animal was anatomically, behaviorally and genetically sophisticated, possessing, at the very beginning of the Cambrian Period, the interacting morphological and neurological complexity needed to fuel both the body plan and behavioral diversification recorded by younger Cambrian skeletal, carbonaceous, and trace fossils.

\section{CONCLUSIONS}

Sedimentary rocks that span the Ediacaran-Cambrian boundary in southern Namibia record two episodes of valley incision and fill. The older valley fill, which includes a $539.4 \pm 1 \mathrm{Ma}$ ash bed near its base, contains unfossiliferous, relatively deep-water marine deposits. In contrast, the younger valley fill consists of lower shoreface deposits containing the trace fossil Treptichnus pedum. These traces are 


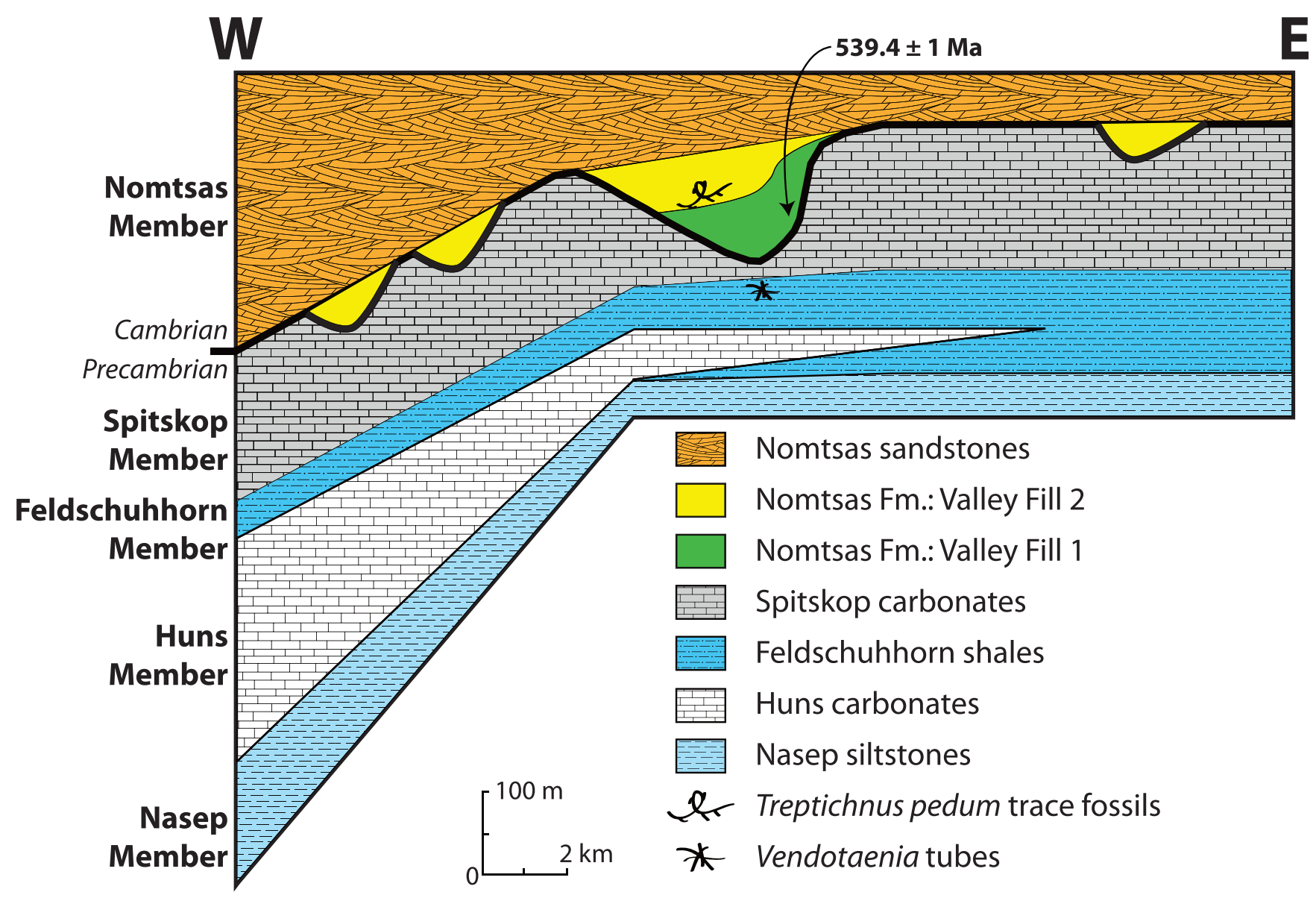

FIGURE 21-Incised valleys on Sonntagsbrunn Farm in their regional context, compare with Germs (1983, fig. 3).

commonly used to mark the base of the Cambrian System, but their first appearance in the Nambian succession reflects sequence development, ecological preference, and taphonomic circumstance, complicating the use of $T$. pedum in biostratigraphy. Excellent preservation facilitates paleobiological interpretation of $T$. pedum, suggesting that genetic, developmental, and behavioral complexity inferred for younger Cambrian body fossils was in place as the period began. These complex traces underscore the view that Cambrian diversification does not simply record an explosion of skeletons, but a true architectural and behavioral radiation that encompassed the entire animal kingdom.

\section{ACKNOWLEDGMENTS}

We are grateful for support for this project from the Agouron Foundation. We thank Roger Swart and Wim Dewulf-Peijenborgh for essential logistic support, Cori Bargmann for discussion of behavioral biology, and Jennifer Griffes and Ralph Milliken for assistance with figure composition. SJ acknowledges funding from the Spanish Ministry of Science and Innovation through grant CGL-2008-0473 (co-financed by Fondo Europeo de Desarrollo Regional [FEDER]) This manuscript was improved with helpful comments from Cornel Olariu and an anonymous reviewer.

\section{REFERENCES}

Aceñolaza, G.F, Germs, G., and Aceñolaza, F.G., 2009, Trace fossils and the agronomic revolution at the Neoproterozoic-Cambrian Transition in southwest Gondwana. Developments in Precambrian Geology, v. 16, p. 339-347.
Allen, G.P., and Posamentier, H.W., 1993, Sequence stratigraphy and facies model of an incised valley fill: The Gironde estuary, France: Journal of Sedimentary Petrology, v. 63, p. 378-391.

Amthor, J.E., Grotzinger, J.P., Schroder, S., Bowring, S.A., Ramezani, J., Martin, M.W., and Matter, A., 2003, Extinction of Cloudina and Namacalathus at the Precambrian-Cambrian boundary in Oman: Geology, v. 31, p. 431-434.

Bartley, J.K., Pope, M., Knoll, A.H., Semikhatov, M.A., and Petrov, P.Y.U., 1998, A Vendian-Cambrian boundary succession from the northwestern margin of the Siberian platform: Stratigraphy, palaeontology, chemostratigraphy and correlation: Geological Magazine, v. 135, p. 473-494.

Blanco, G., Germs, G.J.B., Rajesh, H.M., Chemale, F., Jr., Dussin, I.A., and Justino, D., 2011, Provenance and paleogeography of the Nama group (Ediacaran to Early Palaeozoic, Namibia): Petrography, geochemistry and U-Pb detrital zircon geochronology: Precambrian Research, v. 187, p. 15-32.

Brasier, M.D., Corfield, R.M., Derry, L.A., Rozanov, A.Yu., and Zhuravlev, A.Yu. 1994. Multiple $\delta^{13} \mathrm{C}$ excursions spanning the Cambrian explosion to the Botomian crisis in Siberia: Geology, v. 22, p. 455-458.

Brasier, M.D., Cowie, J., and Taylor, M., 1994, Decision on the PrecambrianCambrian boundary: Episodes, v. 17, p. 3-8.

Brusca, R.C., and Brusca, G.J., 1990, Invertebrates: Sinauer, Sunderland, Massachusetts, $922 \mathrm{p}$.

Chang, A.J., Chronis, N., Karow, D.S., Marletta, M.A., and Bargmann, C.I., 2006, A distributed chemosensory circuit for oxygen preference in C. elegans: PLoS Biology, v. 4, p. 1588-1602.

Cohen, P.A., Bradley, A., Knoll, A.H., Grotzinger, J.P., Jensen, S., Abelson, J., Hand, K., Love, G., Metz, J., Mcloughlin, N., Meister, P., Shepard, R., Tice, M., and Wilson, J.P., 2009, Tubular compression fossils from the Ediacaran Nama Group, Namibia: Journal of Paleontology, v. 83, p. 110-122.

Degnan, B.M., Verwoort, M., Larroux, C., and Richards, G.S., 2009, Early evolution of metazoan transcription factors: Current Opinion in Genetics and Development, v. 19, p. 591-599.

Dibenedetto, S., and Grotzinger, J.P., 2005, Geomorphic evolution of a stormdominated carbonate ramp (c. $549 \mathrm{Ma}$ ), Nama Group, Namibia: Geological Magazine, v. 142, p. 583-604. 
Droser, M.L., and BotTJer, D.J., 1986, A semiquantitative field classification of ichnofabric: Journal of Sedimentary Research, v. 56, p. 558-559.

Droser, M.L., Jensen, S., Gehling, J.G., Myrow, P.M., and Narbonne, G.M., 2002, Lowermost Cambrian ichnofabrics from the Chapel Island Formation, Newfoundland: Implications for Cambrian substrates: PALAIOS, v. 17, p. 3-15.

DziK, J., 2005, Behavioral and anatomical unity of the earliest burrowing animals and the cause of the "Cambrian explosion": Paleobiology, v. 31, p. 503-521.

ERwin, D., 2009, Early origin of the bilaterian developmental toolkit: Philosophical Transactions of the Royal Society B, v. 364, p. 2253-2261.

Fedonkin, M.A., Simonetta, A., and Ivantsov, A.Y., 2007, New data on Kimberella, the Vendian mollusc-like organism (White Sea region, Russia): Palaeoecological and evolutionary implications: Geological Society, London, Special Publications, v. 286, p. 157-179, doi: 10.1144/SP286.12.

Fillion, D., and Pickerill, R.K., 1990, Ichnology of the Upper Cambrian? to Lower Ordovician Bell Island and Wabana groups of eastern Newfoundland, Canada. Palaeontographica Canadiana, v. 7, p. 1-83.

Fürsich, F.T., Pandey, D. K., Kashyab, D., and Wilmsen, M., The trace fossil Ctenopholeus Seilacher \& Hemleben, 1966 from the Jurassic of India and Iran: Distinction from related ichnogenera: Neues Jahrbuch fuer Geologie und Palaontologie Monatshefte, v. 11, p. 641-654.

Gehling, J.G., Jensen, S., Droser, M.L., Myrow, P.M., and Narbonne, G.M., 2001, Burrowing below the basal Cambrian GSSP, Fortune Head, Newfoundland: Geological Magazine, v. 138, p. 213-218.

Germs, G.J.B, 1972, Trace fossils from the Nama Group, south-west Africa. Journal of Paleontology, v. 46, p. 864-870.

Germs, G.J.B., 1983, Implications of a sedimentary facies and depositional environmental analysis of the Nama Group in South West Africa/Namibia, in Miller, R., ed., Evolution of the Damara Orogen of South West Africa/Namibia: Special Publication of the Geological Society of South Africa, v. 11, p. 89114.

GeYer, G., 2005, The Fish River Subgroup in Namibia: Stratigraphy, depositional environments and the Proterozoic-Cambrian problem revisited: Geological Magazine, v. 142, p. 465-498.

Geyer, G., and Uchman, A., 1995, Ichnofossil assemblages from the Nama Group (Neoproterozoic-Lower Cambrian) in Namibia and the Proterozoic-Cambrian boundary problem revisited, in Geyer, G., and Landing, E., eds., MOROCCO '95: The Lower-Middle Cambrian Standard of Western Gondwana: Beringeria Special Issue, v. 2, p. 175-202.

Gresse, P.G., and Germs, G.J.B., 1993, The Nama foreland basin; sedimentation, major unconformity bounded sequences and multisided active margin advance: Precambrian Research, v. 63, p. 247-272.

Grotzinger, J.P., and Miller, R., 2008, The Nama Group, in Miller, R., ed., The Geology of Namibia: Geological Society of Namibia Special Publication, Windhoek, p. 229-272.

Grotzinger, J.P., Bowring, S.A., Saylor, B.Z., and Kaufman, A.J., 1995a, Biostratigraphic and geochronological constraints on early animal evolution: Science, v. 270, p. 598-604.

Grotzinger, J., Adams, E.W., and Schroder, S., 1995b, Microbial-metazoan reefs of the terminal Proterozoic Nama Group (c. 550-543 Ma), Namibia: Geological Magazine, v. 142, p. 499-517.

Ha, H., Henricks, M., Shen, Y., Gabel, C., Fang-Yen, C. M., Qin, Y., ColónRamos, D., Shen, K., Samuel, A.D.T., and Zhang, Y., 2010, Functional organization of a neural network that regulates aversive olfactory learning in Caenorhabditis elegans: Neuron, v. 68, p. 1173-1186.

Jensen, S., 1997, Trace Fossils from the Lower Cambrian Mickwitzia Sandstone, South-Central Sweden: Fossils and Strata, vol. 42: Scandinavian University Press, Oslo, $112 \mathrm{p}$.

Jensen, S., and Grant, S.W.F., 1998, Trace fossils from the Dividalen Group, northern Sweden: Implications for Early Cambrian biostratigraphy of Baltica: Norsk Geologisk Tidsskrift, v. 78, p. 305-317.

Jensen, S., and Runnegar, B.N., 2005, A complex trace fossil from the Spitskop Member (terminal Ediacaran-? Lower Cambrian) of southern Namibia: Geological Magazine, v. 142, p. 561-569, doi: 10.1017/s0016756805000853.

Jensen, S., Saylor, B.Z., Gehling, J.G., and Germs, G.J.B., 2000, Complex trace fossils from the terminal Proterozoic of Namibia: Geology, v. 28, p. 143-146.

King, N., Westbrook, M.J., Young, S.L., Kuo, A., Abedin, M., Chapman, J., Fairclough, S., Hellsten, U., Isogai, Y., Letunic, I., Marr, M., Pincus, D. Putnam, N., Rokas, A., Wright, K.J., Zuzow, R., Dirks, W., Good, M., Goodstein, D., Lemons, D., Li, W., Lyons, J.B., Morris, A., Nichols, S., Richter, D.J., Salamov, A., Sequencing, J.G.I., Bork, P., Lim, W.A., Manning, G., Miller, W.T., Mcginnis, W., Shapiro, H., Tuian, R., Grigoriev, I.V., and Rokhsar, D., 2008, The genome of the choanoflagellate Monosiga brevicollis and the origin of metazoans: Nature, v. 451, p. 783-788, doi: http://www.nature.com/ nature/journal/v451/n7180/suppinfo/nature06617_S1.html.

KNoll, A.H., 2011, The multiple origins of complex multicellularity: Annual Review of Earth and Planetary Sciences, v. 39, p. 217-239.
Lamb, M.P., Myrow, P.M., Lukens, C., Houck, K., and Strauss, J., 2008, Deposits from wave-influenced turbidity currents: Pennsylvanian Minturn Formation, Colorado, USA: Journal of Sedimentary Research, v. 78, p. 480-498, doi: 10.2110/jsr.2008.052.

MacNaughton, R.B., and Narbonne, G.M., 1999, Evolution and ecology of Neoproterozoic lower Cambrian trace fossils, NW Canada: PALAIOS, v. 14, p. 97-115.

Maloof, A.C., Porter, S.M., Moore, J.L., Dudas, F.O., Bowring, S.A., Higgins, J.A., FIKe, D.A., and Eddy, M.P., 2010, The earliest Cambrian record of animals and ocean geochemical change: Geological Society of America Bulletin, v. 122, p. 1731-1774.

Missarzhevsky, V.V., 1989, Drevneyshie skeletnye okamenelosti i stratigrafiya pogranichnykh tolshch dokembriya i kembriya: Akademiya Nauk SSSR, Ordena Trudovogo Krasnogo Znameni Geologicheskiy Institut, Trudy, v. 443, 238 p., 32 pl.

MoczydlowsKa, M., 1991, Acritarch biostratigraphy of the Lower Cambrian and the Precambrian-Cambrian Boundary in Southeast Poland: Fossils and Strata, vol. 29: Universitetsforlaget, Oslo, 127 p.

Mrrow, P.M., 1987, Sedimentology and depositional history of the Chapel Island Formation [late Precambrian-Early Cambrian], southeast Newfoundland: Ph.D. thesis, Memorial University of Newfoundland, St. Johns, Newfoundland, 512 p.

Myrow, P.M., 1992, Pot and gutter casts from the Chapel-Island Formation, southeast Newfoundland: Journal of Sedimentary Petrology, v. 62, p. 992-1007.

Mrrow, P.M., and HiscotT, R.N., 1991, Shallow-water gravity-flow deposits, Chapel Island Formation, southeast Newfoundland, Canada: Sedimentology, v. 38, p. 935-959, doi: 10.1111/j.1365-3091.1991.tb01880.x.

Myrow, P.M., and HiscotT, R.N., 1993, Depositional history and sequence stratigraphy of the Precambrian-Cambrian boundary stratotype section, Chapel Island Formation, southeast Newfoundland: Palaeogeography, Palaeoclimatology, Palaeoecology, v. 104, p. 13-35.

Narbonne, G.M., Myrow, P.M., Landing, E., and Anderson, M.M., 1987, A candidate stratotype for the Precambrian Cambrian boundary, Fortune Head, Burin Peninsula, southeastern Newfoundland: Canadian Journal of Earth Sciences, v. 24 , p. $1277-1293$.

Narbonne, G.M., Saylor, B.Z., and Grotzinger, J.P., 1997, The youngest Ediacaran fossils from Southern Africa: Journal of Paleontology, v. 71, p. 953-967.

Neto De Carvalho, C., 2008, Younger and deeper: Treptichnus (Phycodes) pedum (Seilacher) from the Lower Devonian of Barrancos, Ossa Morena Zone (Portugal): Comunicações Geológicas, v. 95, p. 167-171.

Orlowski, S., and Zylinska, A., 1996, Non-arthropod burrows from the Middle and Late Cambrian of the Holy Cross Mountains, Poland: Acta Palaeontologica Polonica, v. 41 , no. 4, p. $385-409$.

Panganiban, G., Irvine, S.M., Lowe, C., Roehl, H., Corley, L.S., Sherbon, B., Grenier, J.K., Fallon, J.F., Kimble, J., Walker, M., Wray, G.A., Swalla, B.J., Martindale, M.Q., and Carroll, S.B., 1997, The origin and evolution of animal appendages: Proceedings of the National Academy of Sciences, v. 94, p. 5162-5166.

Powilleit, Martin, Kitlar, Jarmila, and Graf, Gerhard, 1994, Particle and fluid bioturbation caused by the priapulid worm Halicryptus spinulosus (v. Seibold): Sarsia, v. 79, no. 2, p. 109-117.

Qian, Yi, and Bengtson, S., 1989, Palaeontology and Biostratigraphy of the Early Cambrian Meishucunian Stage in Yunnan Province, South China: Fossils and Strata, vol. 24: Universitetsforlaget, Oslo, 156 p.

SAYLOR, B.Z., 2003, Sequence stratigraphy and carbonate-siliciclastic mixing in a terminal Proterozoic foreland basin, Urusis Formation, Nama Group, Namibia: Journal of Sedimentary Research, v. 73, p. 264-279.

SAYlor, B.Z., and Grotzinger, J.P., 1996, Reconstruction of important ProterozoicCambrian boundary exposures through the recognition of thrust deformation in the Nama Group of southern Namibia: Communications of the Geological Survey of Namibia, v. 11, p. 1-12.

Saylor, B.Z., Grotzinger, J.P., and Germs, G.J.B., 1995, Sequence stratigraphy and sedimentology of the Neoproterozoic Kuibis and Schwarzrand Subgroups (Nama Group), southwestern Namibia: Precambrian Research, v. 73, p. 153-171.

Sebè-Pedrós, A., Roger, A.J., Lang, F.B., King, N., and Ruiz-Trillo, I., 2010, Ancient origin of the integrin-mediated adhesion and signaling machinery: Proceedings of the National Academy of Sciences, v. 107, p. 10,142-10,147.

SeIlacher, A., 1955, Spuren und Fazies im Unterkambrium: Akademie der Wissenschaften und der Literatur zur Mainz, Mathematisch-Naturwissenschaftliche Klasse, Abhandlungen, v. 10, p. 373-399.

SeIlacher, A., 2007, Trace Fossil Analysis: Springer, Berlin, 226 p.

Seilacher, A., and Hemleben, C., 1966, Beiträge zur Sedimentation und Fossilführung de Hunsruückschiefers, Teil 14. Spurengfauna und Bildungstiefe der Hunsrückschiefer (Unterdevon): Notizblatt des Hessischen Landesamtes für Bodenforschung zu Wiesbaden, v. 94, p. 40-53.

Srivastava, M., Simakov, O., Chapman, J., Fahey, B., Gauthier, M.E.A., Mitros, T., Richards, G.S., Conaco, C., Dacre, M., Hellsten, U., Larroux, C., Putnam, N.H., Stanke, M., Adamska, M., Darling, A., Degnan, S.M., Oakley, T.H., Plachetzki, D.C., Zhai, Y., Adamski, M., Calcino, A., Cummins, S.F., Goodstein, D.M., Harris, C., Jackson, D.J., Leys, S.P., Shu, S., Woodcroft, 
B.J., Vervoort, M., Kosik, K.S., Manning, G., Degnan, B.M., and Rokhsar, D.S., 2010, The Amphimedon queenslandica genome and the evolution of animal complexity: Nature, v. 466, p. 720-726, doi: http://www.nature.com/nature/journal/ v466/n7307/abs/nature09201.html\#supplementary-information.

Strauss, H., Bengtson, S., Myrow, P.M., and Vidal, G., 1992, Stable isotope geochemistry and palynology of the Late Precambrian to Early Cambrian sequence in Newfoundland: Canadian Journal of Earth Sciences, v. 29, p. 1662-1673.

TALLING, P.J., 1998, How and where do incised valleys form if sea level remains above the shelf edge?: Geology, v. 26, p. 87-90.

Vannier, J., Calandra, I., Gaillard, C., and Zylinska, A., 2010, Priapulid worms: Pioneer horizontal burrowers at the Precambrian-Cambrian boundary: Geology, v. 38, p. 711-714, doi: 10.1130/g30829.1.
Webster, B.L., Copley, R.R., Jenner, R.A., Macknezie-Dodds, J.J., Bourlat, S.J., Rota-Stabelli, O., LitTlewood, D.T.J., and Telford, M.J., 2006, Mitogenomics and phylogenomics reveal priapulid worms as extant models of ancestral Ecdysozaon: Evolution and Development, v. 8, p. 502-510.

Zattuin, B.A, Dalrymple, R.W., and Boyd, R., 1994, The stratigraphic organization of incised valley systems associated with relative sea-level change, in Dalrymple, R.W., Boyd, R., and Zaitlin, B.A., eds., Incised Valley Systems: Origin and Sedimentary Sequences: Society for Sedimentary Geology (SEPM) Special Publication, v. 51, p. 45-60. Zimmer, M., Gray, J.M., Pokala, N., Chang, A.J., Karow, D.S., Marletta, M.A., Hudson, M.L., Morton, D.B., Chronis, N., and Bargmann, C.I., 2009, Neurons Detect Increases and Decreases in Oxygen Levels Using Distinct Guanylate Cyclases: Neuron, v. 61, p. 865-879. 